\title{
Effect of the Internet on Services Export Diversification
}

\author{
Sèna Kimm Gnangnon ${ }^{1+}$ \\ ${ }^{1}$ World Trade Organization, Switzerland
}

\begin{abstract}
This study empirically examines the effect of Internet access on services export diversification. A panel dataset containing 131 countries is analyzed over 1995-2014 and shows that greater access to the Internet is positively associated with services export diversification. This outcome applies to both high-income and developing countries, and particularly to least developed countries (LDCs) among developing countries. Additionally, the effect of Internet access on services export product diversification translates to countries' level of innovation, merchandise exports, including export product concentration and size of foreign direct investment (FDI) inflows. These findings highlight the need for developing digital infrastructure and regulations that would facilitate access to the Internet, particularly in developing countries. The international community must focus on developing countries, particularly LDCs, by helping them to develop the requisite digital infrastructure and regulations to better participate in international trade, especially through greater series export diversification.
\end{abstract}

Keywords: Internet access, Services export diversification, Innovation, Merchandise exports, Export product diversification, Foreign Direct Investment inflows

\section{Introduction}

The economic effects of information and communication technology (ICT), and particularly the access and use of the Internet (henceforth referred to as "the Internet"), has become the focus of policymakers, researchers, and scholars. Specifically, the development of the services sector due to, among other things, the rapid development of ICT and the Internet, has led economists to recognize the tradability of services, which were long considered a residual and nontradable sector of the economy. This has led to research on the impact of ICT, including the impact of the Internet on trade in services in particular, and on trade performance in general. The rapid development of the services sector is exemplified by statistics. For example, World Trade Organization (WTO) (2019a) reported that in 2018, the volume of world trade in commercial

\footnotetext{
+Corresponding Author: Sèna Kimm Gnangnon

Economist, World Trade Organization, Rue de Lausanne 154, CH-1211 Geneva 21, Switzerland,

Email: SenaKimm.Gnangnon@wto.org
}

Acknowledgments: This paper represents the personal opinions of individual staff members of the WTO and is not meant to represent the position or opinions of the WTO or its Members, nor the official position of any staff members. 
services $(7.7 \%)$ grew faster than that world merchandise trade (3\%). In the 2019 WTO report titled "The future of services trade" (WTO, 2019b), Director General Roberto Azevêdo noted the key role played by services in today's economies: it generates more than two-thirds of the economic output and plays an increasingly important role in international trade, including as a key driver of global value chains. Furthermore, services account for more than two-thirds of jobs in developing countries, and four-fifths of employment in developed ones.1) The WTO report showed that the contribution of services to the Gross Domestic Product (GDP) of nations has been rising since 2005 (WTO, 2019b: page 16), and trade in commercial services has increased more rapidly than trade in goods particularly since 2008 (WTO, 2019b: page 14).

Several studies have emphasized the role of services in global and regional value chains as intermediate inputs to manufacturing2) (e.g., Baldwin et al., 2015; Hoekman \& Shepherd, 2017; Lanz \& Maurer, 2015). Many researchers have highlighted the importance of the services sector for economic growth, poverty reduction, and development, including sustainable development (e.g., Adlung, 2007; Balchin et al., 2016; Fiorini \& Hoekman, 2018; François \& Hoekman, 2010; Hoekman, 2017; Hoekman \& Mattoo, 2008; McGuire, 2002; Roy, 2019). It is now recognized that by providing opportunities for greater income, productivity, employment, investment, and trade, the services sector plays a significant role in the global economy and countries'3) growth and development. In her introductory remarks at a meeting held at the United Nations Office based in Geneva, UNCTAD4) Deputy Secretary-General Isabelle Durant stated that "the services sector is responsible for two-thirds of total productivity growth in developing countries." ${ }^{5}$ )

Although a rich body of work exists on the determinants of trade flows (either total trade, i.e., exports and imports of goods and services, or only trade in goods), relatively few6) have explored the determinants of trade in services (and particularly services exports) and among them, only few have considered the effect of the Internet7) on services exports (Choi, 2010;

1) See the statement of the Director General online at: https://www.wto.org/english/news_e/spra_e/spra286_e.htm

2) François and Hoekman (2010) noted that services contribute to global economic growth through input-output linkages.

3) See information online at: https://unctad.org/en/Pages/DITC/Trade-in-Services.aspx

4) UNCTAD refers to the United Nations Conference on Trade and Development.

5) This is part of the statement delivered at the seventh session of UNCTAD's multi-year expert meeting on trade, services, and development. See the information online at: https://unctad.org/en/pages/newsdetails.aspx?OriginalVersi onID $=2069 \&$ Sitemap_x0020_Taxonomy $=$ UNCTAD $\% 20$ Home;

6) Studies concerning the determinants of international trade in services include, for example, Abeliansky and Hilbert (2017); Anand et al. (2012); Ansari and Ojemakinde (2003); Bianchi and Mathews (2016); Choi (2010); Chitgupi (2019); Clarke (2008); Clarke and Wallsten (2006); Eichengreen and Gupta (2013a, b); Fernandes et al., 2019; Fink et al., 2005; Freund and Weinhold (2002, 2004); Gani and Clemes (2013); Gnangnon and Iyer (2018); Goswami et al. (2012); Hoekman and Shingal (2017); Huang and Viana (1995); Kandilov and Grennes (2010); Karam and Zaki (2013); Kimura and Lee (2006); Lin (2015); Mattes et al. (2012); Meijers (2012); Mirza and Nicoletti (2004); Morgan and Snowden (2007); Li et al. (2003, 2005); Portugal-Perez and Wilson (2012); Riker (2014); Ruey-Jer and Kim (2019); Sahoo and Dash (2014, 2017); Sandra and Pelin (2012); Shingal (2010); Sapir and Lutz (1981); Sandeep (2011); Timmis (2012); Vemuri and Siddiqi (2009); Visser (2019); Wong et al. (2009); and Wren-Lewis and Driver (1998). 
Freund \& Weinhold, 2002; Gnangnon \& Iyer, 2018). Several empirical studies that focus on the determinants of services exports have controlled for the effect of ICT (proxied by the level of Internet access). The Internet could promote international trade by facilitating commercial transactions (e.g., Vemuri \& Siddiqi, 2009), reducing the communication costs between the exporting and importing countries (e.g., Fink et al., 2005), reducing the ill effects of geographical remoteness on countries' integration into the world trade in commercial services (Gnangnon \& Iyer, 2018), promoting FDI inflows (e.g., Choi, 2003; Ibrahim et al., 2019), enhancing competition, and reducing the market-specific sunk costs for trade in goods (e.g., Freund \& Weinhold, 2004). Gani and Clemes (2013) contended that advances in digital information technology significantly impact the services sector as it allows acceleration in the creation of networks, new markets, and trade transactions among new trading partners.

Similarly, while several studies exist on the determinants of export product diversification, $\left.{ }^{8}\right)$ there are none on the determinants of services export diversification and on the effect of ICT, and particularly on the impact of the Internet usage on services export diversification. However, two recent studies focus on services export diversification. First, Sahoo and Dash (2017) assessed the macroeconomic determinants of services exports in India emphasizing the structure of India's services exports (i.e., traditional versus modern services). Second, Anand et al. (2012) empirically examined the determinants and impact of the sophistication of services and goods exports. These studies have underlined the importance of modern services and the sophistication of manufactured and service exports for countries' economic growth, particularly developing and low-income countries. The lack of studies on the services export diversification is surprising given the rapid internationalization of services and the significant role of the services sector in the economic and social development of a country.

This study addresses this gap in the literature by investigating the effect of the Internet on services export diversification. Thus, it contributes to the literature on the determinants of export diversification in general, and complements the literature on the effect of the Internet on export product diversification in particular. Lapatinas (2019) is the only study to have empirically examined the effect of the Internet on economic sophistication (i.e., the sophistication of exported products). The study found that the Internet positively impacts the sophistication of exported products.

Given the rapid progress of ICT, significance of the Internet in international trade, and the increasing role of the services (including modern services) sector for economic development and growth, the relationship between the Internet and services export diversification gains

7) A literature review on the effect of the Internet on international trade and on other macroeconomic indicators could be found in Gnangnon and Iyer (2018).

8) Studies include, for example, Adityaa and Acharyya (2015); Agosin et al. (2012); Ali (2017); Amighini and Sanfilipo (2014); Bahar and Santos (2018); Gnangnon and Roberts (2017); Gnangnon (2019a, 2019b); Harding and Javorcik (2012); Hausmann et al. (2007); Imbs and Wacziarg (2003); Osakwe et al. (2018); Parteka and Tamberi (2013); Vardanyan (2019); and Zhu and Fu (2013). 
importance. Therefore, traditional and modern services must be distinguished. Few studies have classified services into traditional and modern, although there is no consensus on types of services that could be included in each of these categories. Eichengreen and Gupta(2013b) stated that traditional services include trade and transport, tourism, financial services, and insurance, while modern services include communications, computer, information, and other related services. However, this distinction is not straightforward because insurance and finance could be included in either category (Eichengreen \& Poonam, 2013b: page 2, footnote 5). Sahoo and Dash (2017) followed Baumol (1985), Ghani and Kharas (2010), and Eichengreen and Gupta (2013a) and classified commercial services into traditional and modern services. Modern services refer to transportability and tradability, financial services, insurance, business processing, and software services, while traditional services include transport and travel services (see also the study of Sahoo \& Daho, 2014 on the determinants of exports of modern services in India).

This empirical study on the effect of the Internet on services export diversification was conducted using an unbalanced panel dataset of 131 countries (both developed and developing countries) during 1995-2014, and the two-step system of generalized methods of moments (GMM) approach. The study findings showed that greater Internet access promotes services export diversification in the full sample as well as in developed and developing countries, and particularly in least developed countries (LDCs). Additionally, the effect of the Internet access on services export diversification in the sample countries depends on the level of innovation, merchandise exports growth, level of export product concentration, and the size of foreign direct investment (FDI) inflows.

This study is presented as follows. Section 2 discusses theoretically how the Internet affects services export diversification. Section 3 presents the model specification and the econometric method that helps to perform in the empirical analysis of the effect of the Internet on services export diversification. Section 4 interprets the empirical results. Section 5 deepens the anaoysis, and section 6 concludes.

\section{Theoretical Motivations: How can the Intemet Influence Services Export Divensification?}

This study contends that the Internet influences services export diversification path through its effects on innovation and on goods exports, particularly on export product sophistication. Before turning to the discussion on the channels through which the Internet can affect services export diversification, it is worth highlighting the relationship between the increase in the volume of services exports and services export diversification. Growth in services exports can be attributed to an increase in the volume of the existing services exports, referred to as the growth 
of services exports at the intensive margins, or to the rise in the volume of services exports due to the introduction of new services export items, referred to as the growth of the volume of services exports at the extensive margins.

\section{A. Effect of the internet on services export diversification through innovation}

Greater access to the Internet promotes services export diversification via its impact on innovation. Promoting access to the Internet gives people the opportunity to access knowledge information, including information on clients, suppliers, and competitors for trading firms, and ideas (e.g., Arthur, 2007; Paunov \& Rollo, 2016). Paunov and Rollo (2016) listed the positive effects of Internet access. Promoting Internet access helps trading firms acquire information on customer preferences and facilitates the identification of market opportunities for new products and services. It also helps reduce the uncertainty about future market demands for new products, and allows firms to rely on users' feedback to develop new products and services. Studies also noted that the Internet access allows better communication with firms' suppliers, thereby allowing them to learn more about technological possibilities and firms' needs. Firms benefit from the positive network effects through exchanges with others via Internet. Finally, Internet access contributes to improving firms' decision making. Acs et al. (1994) argued that small firms could benefit better than larger firms from knowledge spillovers resulting from the Internet access because the internal sources of knowledge and the accrued benefits from their own R\&D investments are limited (e.g., Cohen, 2010; Klepper \& Simons, 2005). Informal firms have limited resources that prevent them from building knowledge networks, innovating, and hence benefiting from international trade. Jensen (2007) argued that greater Internet access would allow firms to overcome the drawbacks of limited resources and build knowledge networks, resulting in sizable gains, including innovation. Paunov (2013) and OECD (2015) stated that the Internet contributes to enhancing inclusive innovation in the emerging and developing countries by increasing the number of innovating firms.

Innovation introduces new export products or expands the range of products that a country can produce and export (e.g., Krugman, 1979; Dollar, 1986; Grossman \& Helpman, 1989) and hence promote export product diversification. In turn, export product diversification can promote modern services and facilitate services export diversification, that is, across many types of services in the economy, including the move from traditional export services toward modern services. Chen (2013) empirically found that innovation (measured by the number of patents) stimulates both export products at the extensive margins (i.e., the number of products exported from a country) and export products at the intensive margins (i.e., the export value of each product from a country). As greater access to the Internet also promotes the sophistication of exported products (see Lapatinas, 2019), greater access to the Internet would ultimately 
enhance services export diversification.

In addition to its services export diversification effect through the innovation channel, the Internet can also influence export product diversification, which in turn, can exert a positive effect on services export diversification through its positive FDI inflows9)effect. Choi (2003) used bilateral FDI data from 14 source countries and 53 host countries to provide empirical evidence that the Internet is associated with higher FDI inflows to a host country through its positive effect on productivity. Besides, several studies (e.g., Amighini \& Sanfilippo, 2014; Gnangnon \& Roberts, 2017; Harding \& Javorcik, 2012; Zhu \& Fu, 2013) reported a positive effect of FDI inflows on export upgrading, including export product diversification. As FDI inflows influence the volume of services exports of countries (e.g., Ansari \& Ojemakinde, 2003; Grünfeld \& Moxnes, 2003; Huang \& Viana, 1995; Wren-Lewis \& Driver, 1998; Wong et al., 2009), greater access to the Internet can ultimately influence countries' services export diversification path, either through greater services export diversification (i.e., by inducing services export growth at the extensive margins) or through a higher degree of services export concentration (by increasing services export growth at the intensive margins).

\section{B. Effect of the intemet on services export diversification through services exports and goods exports}

Majority of the existing studies showed that the Internet has a positive impact on international trade, including total trade flows (i.e., exports and imports of goods and services), trade in goods (including goods exports), and trade in services (including services exports). In terms of the effect of the Internet on services exports, Freund and Weinhold (2002) found that the Internet has promoted services exports to the United States. Choi (2010) empirically demonstrated that improvement in Internet access has facilitated countries' trade in services, including services exports and imports, with the impact on services exports being higher than that on imports. Gnangnon and Iyer (2018) showed that a country improves its integration into the world trade in commercial services market when it narrows the gap between its Internet penetration rate and that of the rest of the world. Furthermore, by narrowing the Internet gap, countries can mitigate the adverse effect of geographical remoteness on their integration into the world trade in commercial services. As the Internet contributes to expanding commercial services exports, it can induce higher services export concentration if increased Internet access is associated with the rise in the export of services products in which the country enjoys a comparative advantage. Alternatively, it would lead to services export diversification if greater access to the Internet helps promote new exportable services items.

9) For example, Gnangnon (2019c) obtained empirically that export product diversification leads to higher FDI inflows, including in countries that open-up their economies to international trade. 
Greater Internet access also influences countries' services export diversification path through its effect on the trade in goods. In fact, studies ${ }^{10)}$ on the effect of Internet access on international trade in goods underlined its role in promoting services exports. Simultaneously, some studies have also examined the effect of international trade in goods, in particular that of goods exports on services exports. Studies highlighted the closed inter-relations between services and goods exports (Broussolle, 2012; Eichengreen \& Gupta, 2013; Lennon, 2008; Lodefalk, 2012; Nordås, 2010), because services can be byproducts of (or inputs of) or accompany many traded goods, and vice versa. For example, Stern and Hoekman (1987) and Deardoff (2001) noted that the actual cross-border traded services are the byproducts of international manufacturing activities or transactions. Similarly, Hoekman and Mattoo (2008) and François and Hoekman (2010) contended that the use of knowledge-intensive business, financial, transport, and communication services in manufacturing production promotes international trade in services. According to Broussolle (2012), the exports of business services sectors depend on the demand from manufacturing, both through goods exports and FDI. Eichengreen and Gupta (2013a) and Sahoo and Dash (2014) emphasized that exports of goods increased the demand for services exports through the "network effect." According to the authors, the network effect occurs when, given the network it has established through a higher integration into the international markets of goods, a country could expand its services exports. They provided empirical evidence that goods exports induce higher services exports. Other empirical studies such as Ceglowski (2006), Deardorff (2001), Kimura and Lee (2006) and Karmali and Sudarsan (2008) found a positive effect of trade in goods on trade in services. Similarly, Gnangnon and Shishir (2016) found that export product diversification has a positive and significant effect on commercial services exports in LDCs. Overall, by inducing higher services exports through its positive effect on international trade in goods, Internet development could lead to services export concentration or diversification, depending on whether the rise in the volume of services exports is attributed to services export growth at the intensive or extensive margins.

\section{Model Specification and Econometric Strategy}

\section{A. Model specification}

There is no unified theoretical framework on the determinants of services export diversification.

10) See, for example, Abeliansky and Hilbert (2017); Anand et al. (2012); Bianchi and Mathews (2016); Choi (2010); Chitgupi, 2019; Clarke (2008); Eichengreen and Gupta (2013a, b); Fernandes et al., 2019; Fink et al., 2005; Freund and Weinhold (2004); Gnangnon and Iyer (2018); Goswami et al. (2012); Lee (2006); Lin (2015); Mattes et al. (2012); Ruey-Jer and Kim, 2019; Sahoo and Dash (2014, 2017); Sandeep (2011); Timmis (2012); Vemuri and Siddiqi (2009); Visser (2019). 
However, the international trade theory that applies to trade in goods also applies to trade in services (e.g., Kimura \& Lee, 2006; Nyahoho, 2010; van der Marel, 2012). Therefore, this study draws from previous works on the determinants of export product diversification and from Anand et al. (2012) to empirically analyze the effect of Internet access on services export diversification. Accordingly, in addition to the variable capturing Internet access, this study includes several control variables that are both determinants of services export diversification and potentially influence the effect of Internet development on services export diversification. These variables include real per capita income (denoted "GDPC"), population size (denoted "POP"), degree of trade openness (denoted "OPEN"), level of human capital accumulated (denoted "EDU"), size of FDI inflows, depth of financial development (denoted "FINDEV"), and institutional and governance quality (denoted "INST").

We postulate the following model specification:

$$
\begin{aligned}
& S E C_{i t}=\alpha_{0}+\alpha_{1} S E C_{i t-1}+\alpha_{2} I N T E R N E T_{i t}+\alpha_{3} \log (G D P C)_{i t}+\alpha_{4} \log (\text { OPEN })_{i t} \\
& +\alpha_{5} F_{D I C A P_{i t}}+\alpha_{6} \text { FINDEV }_{i t}+\alpha_{7} E D U_{i t}+\alpha_{8} I N S T_{i t}+\alpha_{9} \log (P O P)_{i t}+\mu_{i}+\lambda_{t}+\omega_{i t}
\end{aligned}
$$

where $i$ refers to a given country and $t$ denotes the time. Based on the data available, the analysis used an unbalanced panel dataset containing 131 countries (both developed and developing countries) during 1995-2014. Particularly, nonoverlapping data of 3-year average for the variables were used to smooth out the effect of business cycles on the variables. Overall, six sub-periods were observed: 1995-1997, 1998-2000, 2001-2003, 2004-2006, 2007-2010, and 2011-2014 (the last two sub-periods cover 4 years).

$\alpha_{0}$ to $\alpha_{9}$ are the parameters to be estimated. $\mu_{i}$ represents countries' fixed effects (unobservable time-invariant characteristics that influence services export diversification path); $\varepsilon_{i t}$ is a well-behaving error term. $\lambda_{t}$ are the time dummies representing global shocks affecting together all countries' services export diversification path. All variables are described in Appendix 1. Appendix 2 presents the list of countries used in the full sample and in the various subsamples. Appendix 3 shows the descriptive statistics of all variables used in the model.

The dependent variable "SEC" is the measure of the concentration of services export. To measure the extent of services export diversification, two indicators are drawn from the literature on the determinants of export product diversification (e.g., Agosin et al., 2012; Cadot et al., 2011). The first main indicator used is the well-known Herfindahl index of export concentration (or the Hirschman-Herfindahl index (HHI)). It is computed as the sum of the squared shares of each export line $k$ (with the amount exported) in total services exports. The formula used is $H H I=\frac{\sum_{k} s_{k}^{2}-1 / n}{1 / n}$, where $s_{k}={ }^{x_{k}} / \sum_{k=1}^{n} x_{k}$ represents the share of export line $k$ (with the amount exported $x_{k}$ ) in total exports: $x_{k}$ refers to the amount of services exports associated 
with the services line $k ; n$ represents the total number of the services export lines $(k)$ and $n=\sum_{k=1}^{n} k$. The computed variable has been normalized so that its values range between 0 and 100. Higher values of this index reflect greater services export concentration, and lower values indicate greater services export diversification. The other measure of SEC, the Theil index of services export concentration (denoted "THEIL"), is used for robustness check analysis. Theil indicator of services export concentration is computed using the following formula (see Agosin et al, 2012; Cadot et al., 2011): THEIL $=\frac{1}{n} \sum_{k=1}^{n} \frac{x_{k}}{\mu} \ln \left(\frac{x_{k}}{\mu}\right)$, where $\mu=\frac{1}{n} \sum_{k=1}^{n} x_{k} ; n$ represents the total number of the services export lines $(k)$ and $n=\sum_{k=1}^{n} k ; x_{k}$ stands for the amount of services exports associated with the services line $k$. The variable "THEIL" has been normalized so that its values range between 0 and 100. A rise in the values of this index reflects a higher level of services export concentration, while lower values indicate greater services export diversification. To compute each of these indicators, this study used the database developed by the International Monetary Fund (IMF) (see Loungani et al., 2017) on 11 major sectors of services (categories of services). Specifically, the study used disaggregated data on services exports at the 2-digit level, and focused only on commercial ${ }^{11)}$ services exports, which exclude government goods and services exports. The introduction of the lag of the dependent variable as a right-hand side regressor captures the eventual state dependence in the services export diversification path of recipient countries. This approach is also based on earlier studies on the determinants of export product diversification, where the latter exhibits persistence over time. This also applies to services export diversification. Finally, the use of the lag of the dependent variable also allows to control for omitted variables in the model specification.

"INTERNET," the key variable of interest, is the Internet penetration rate, that is, the share (\%) of individuals using the Internet in the total population. Clark (2008) argued that this variable is a general proxy for investment in information and technology because firms connected to the Internet invest more in other information technologies than firms that are not connected. Thus, the estimated coefficient of the variable "INTERNET" partially reflects the effect of more general investment in information and technology rather than just the effect of Internet access (Clark, 2008: page 19). Studies such as Ibrahim et al. (2019) underlined that Internet penetration can be considered as a proxy for ICT among other proxies for ICT.

Consider the expected effects of each control variable included in model (1) on services

11) The literature has classified the activities of the services sector into market and nonmarket services (see, e.g., Gani \& Clemes, 2013). The category of market activities encompasses producer services (e.g., banking and finance), distribution services (e.g., transport and storage), personal services (e.g., hotels and restaurants), and communications (e.g., the Internet). The category of nonmarket services refers to social services, including health, education, and housing. Thus, in this study, commercial services are included in the category of market services. In fact, commercial services include all services categories except government goods and services and are subdivided into goods-related services, transport, travel, and other commercial services (the latter including financial services and other business services) (see WTO, 2019). 
export concentration. The real per capita income variable has been introduced in the model specification to consider countries' development level (proxied by the real per capita income) that could affect their degree of services export diversification. This variable also captures economies of scale (e.g., Marvasti, 1994; Li et al., 2005; Nyahoho, 2010; Sapir \& Lutz, 1981; Schulze, 1999). Economies of scale contribute to the emergence of demand for new services, and hence induce services production and export diversification. The trade theory, including monopolistic competition, developed by Krugman (1981) showed that economies of scale are one of the main determinants of trade in general, and trade in services in particular. Linder (1961) argued that per capita income indicates the demand structure for goods and services. Helpman and Krugman (1985) suggested that as differentiated products require capital-intensive technology, an increase in per capita income can be used as a proxy for high capital-labor ratio. Finally, if the rise in the real per capita income is associated with the diversification of export product baskets, including manufacturing exports, it could generate services export diversification.

The population size variable supplements the real per capita income in capturing the size of a given country. Empirical studies on the determinants of services exports have posited that bigger states (measured by their population size) also have a larger share of services in GDP (e.g., Goswami et al., 2012) because innumerable services cater directly to the final consumer. Therefore, a rise in the population size can induce higher demand for services, and hence an expansion of the services sector. This can result in either services production and services export concentration or services export diversification.

Existing studies consider market or trade openness as an important factor for services trade. This study contends that trade openness promotes services export diversification through positive spillovers related to the knowledge and technology embodied in the imported goods and services, promotes of R\&D activities, and provides greater access to investment and intermediate goods (e.g., Agosin et al., 2012; Grossman \& Helpman, 1991; Coe \& Helpman 1995; Costas et al., 2008; Yanikkaya, 2003), and the possibility of market extension (e.g., Dennis \& Shepherd, 2011). This effect directly acts through the development of differentiated services items or indirectly through greater export product diversification. However, if greater trade openness results in countries further developing goods and services activities in their sectors of comparative advantage, it would result in higher export product concentration or greater services export diversification or both.

The variable "FDICAP" measures the real per capita FDI inflows (see Appendix 1 for its computation). As noted earlier, FDI inflows affect countries' volume of services exports (e.g., Ansari \& Ojemakinde, 2003; Grünfeld \& Moxnes, 2003; Huang \& Viana, 1995; Wren-Lewis $\&$ Driver, 1998; Wong et al., 2009) and, hence, induce either a greater services export diversification by promoting services export growth at the extensive margins or by being associated with 
a higher degree of services export concentration (i.e., generating services export growth at the intensive margins). The introduction of this variable in the model ensures that any effect of the Internet on services export diversification does not translate through FDI inflows.

An educated workforce is considered a key determinant of services exports, particularly than for goods exports (e.g., Sahoo \& Dash, 2017; Anand et al, 2011). Following Agosin et al. (2012) for the case of export product diversification, this study contends that an improvement in human capital, and hence of the skills of the educated workforce would translate into services export diversification if this workforce is employed in new services activities oriented toward international trade. In contrast, if the educated workforce is employed for the expansion of production and export of existing services activities, higher education will result in a higher degree of services export concentration. Incidentally, if human capital accumulation is associated with export product diversification, it induces greater services export diversification through the channels described in section 2. Similarly, if better education induces a higher degree of export product concentration notably on primary commodities, which is the goods sector of comparative advantage of many developing countries, it will result in a higher level of services export concentration.

The development of the financial sector is also an important determinant of trade in services, mainly services exports (e.g., Sahoo \& Dash, 2017). Its effect on services export diversification depends on whether financing-dependent firms use the financial resources to develop more differentiated products and services, or whether they invest these resources on the existing services activities. If these firms concentrate their financial resources on existing goods and services activities where the economy already enjoys a competitive advantage, greater financial development will be associated with product and/or services export concentration (see also Agosin et al., 2012 for the case of the effect of financial development on export product diversification).

Finally, institutional and governance quality are important factors underpinning the development of services trade (e.g., Gani \& Clemes, 2016), including the promotion of trade in goods, notably manufacturing export goods and export product diversification (e.g., Amighini \& Sanfilipo, 2014; Faruq, 2011; Hausmann et al., 2007; Zhu \& Fu, 2013). Consequently, better institutional and governance quality is associated with services export diversification if it allows trading firms to develop new goods and services. Conversely, improvements in the quality of institutions and governance could be associated with services export concentration if such an improvement increased the volumes of exports of existing goods and services.

\section{B. Estimation strategy}

To understand the effect of the Internet on services export diversification, two standard econometric estimators were used to estimate the static version of model (1), that is, without 
the one-period lag of the dependent variable. These estimators are the within fixed-effects estimator (FE) and feasible generalized least squares (FGLS) with panel-specific AR(1) (i.e., autocorrelation of order 1 for each panel). Table 1 presents the results of these estimations, including with each of the indicators "HHI" and "THEIL" as dependent variable. These estimates might be biased, given that some regressors in model (1) could be endogenous (endogeneity due to the simultaneity bias). Moreover, the static specification of model (1) is likely to suffer from the omission of the $\operatorname{lag}(\mathrm{s})$ of the dependent variable as a regressor, given that the latter helps in considering the persistence of the dependent variable.

Table 1. Effect of the Internet Penetration on Services Exports Concentration

Estimators: FE and FGLS (with Panel-Specific First Order Autocorrelation)

\begin{tabular}{|c|c|c|c|c|}
\hline \multirow[b]{2}{*}{ Variables } & \multicolumn{2}{|c|}{$\mathrm{FE}$} & \multicolumn{2}{|c|}{ FGLS } \\
\hline & $\begin{array}{c}\mathrm{HHI} \\
(1)\end{array}$ & $\begin{array}{l}\text { THEIL } \\
\text { (2) }\end{array}$ & $\begin{array}{c}\mathrm{HHI} \\
\text { (3) }\end{array}$ & $\begin{array}{l}\text { THEIL } \\
\text { (4) }\end{array}$ \\
\hline \multirow[t]{2}{*}{ INTERNET } & $-0.162 * * *$ & $-0.289 * * *$ & $-0.179 * * *$ & $-0.0919 * *$ \\
\hline & $(0.0210)$ & $(0.0706)$ & $(0.0239)$ & $(0.0416)$ \\
\hline \multirow[t]{2}{*}{ FINDEV } & -0.0137 & 0.0314 & $0.0416^{* * *}$ & $0.118 * * *$ \\
\hline & $(0.0216)$ & $(0.0260)$ & $(0.00909)$ & $(0.0145)$ \\
\hline \multirow[t]{2}{*}{$\log (\mathrm{GDPC})$} & $-13.08 * * *$ & $37.69 * * *$ & -0.794 & -0.180 \\
\hline & (2.489) & (7.205) & $(1.111)$ & $(0.884)$ \\
\hline \multirow[t]{2}{*}{ FDICAP } & 0.0923 & 0.242 & $0.259^{*}$ & $0.860 * * *$ \\
\hline & $(0.138)$ & $(0.322)$ & $(0.155)$ & $(0.289)$ \\
\hline \multirow[t]{2}{*}{ INST } & $5.409 * * *$ & $5.319 * * *$ & $1.664 * * *$ & -0.705 \\
\hline & $(1.266)$ & $(0.883)$ & $(0.572)$ & $(0.507)$ \\
\hline \multirow[t]{2}{*}{ EDU } & $0.115 * * *$ & 0.0377 & $-0.143 * * *$ & 0.0307 \\
\hline & $(0.0212)$ & $(0.0396)$ & $(0.0154)$ & $(0.0198)$ \\
\hline \multirow[t]{2}{*}{$\log (\mathrm{OPEN})$} & 1.199 & -0.267 & -0.0230 & 1.000 \\
\hline & (1.149) & $(1.723)$ & $(0.647)$ & $(0.659)$ \\
\hline \multirow[t]{2}{*}{$\log (\mathrm{POP})$} & 1.414 & $40.47 * * *$ & $1.626^{* * *}$ & $1.334 * *$ \\
\hline & $(3.871)$ & $(2.288)$ & $(0.608)$ & $(0.657)$ \\
\hline \multirow[t]{2}{*}{ Constant } & $124.5^{*}$ & $-917.5^{* * *}$ & $58.12 * * *$ & 30.62 \\
\hline & $(74.31)$ & $(58.53)$ & $(18.90)$ & (19.85) \\
\hline Observations - Countries & $559-131$ & $559-131$ & $550-122$ & $550-122$ \\
\hline Within $\mathrm{R}^{2}$ / Pseudo $\mathrm{R}^{2}$ & 0.0565 & 0.1598 & 0.3728 & 0.2097 \\
\hline
\end{tabular}

(Note) $*$ p-value $<0.1 ; *$ p-value $<0.05 ; * * *$ p-value $<0.01$. Robust standard errors are in parenthesis. The Pseudo R2 has been calculated for regressions based on the FGLS estimator, as the correlation coefficient between the dependent variable and its predicted values.

To address the issues of endogeneity, we followed the macro-empirical literature on the determinants of export product diversification and used the two-step system GMM estimator 
proposed by Arellano and Bover (1995) and Blundell and Bond (1998). This estimator is suitable for dynamic panels with a small-time span and a large cross section. It addresses the endogeneity bias resulting from the correlation between the unobserved time-invariant specific effects of countries and the lagged dependent variable, which generates the so-called Nickell bias (Nickell, 1981). The endogeneity problems induced by bi-directional causality between regressors and the dependent variable are also addressed. The two-step system GMM estimator has several advantages over the first-difference estimator proposed by Arellano and Bond (1991). Arellano and Bover (1995) and Blundell and Bond (1998) emphasized the limitations of the instrumentation approach used in the first difference-GMM estimator and highlighted that when explanatory variables persist, instrumenting the endogenous variables through the lagged values of the first difference of these variables in the difference GMM approach generates weak instruments. Therefore, the two-step system GMM estimator uses additional moment conditions and reduces the potential biases and inaccuracies associated with the difference estimator. In addition, applying the difference GMM estimator to dynamic unbalanced panels has the disadvantage of widening the gaps (Roodman, 2009). The two-step system GMM estimator combines an equation in differences with an equation in levels where lagged first differences are used as instruments for the levels equation, and lagged levels are used as instruments for the first-difference equation. The validity of this estimator is examined based on three tests, including the Arellano-Bond test of the presence of first-order serial correlation in the error term (denoted $\operatorname{AR}(1)$ ) and the test of the absence of second-order autocorrelation in the error term (denoted $\operatorname{AR}(2)$ ). The third is the Sargan/Hansen test of over-identifying restrictions (OID), which helps in testing the joint validity of the instruments used in the estimations. Finally, the number of instruments used in the regressions must be fewer than the number of countries to ensure the powerfulness of the aforementioned tests (e.g., Bowsher, 2002; Roodman, 2009). The regressions used a maximum of four lags of the dependent variable and a maximum of four lags of endogenous variables.

In this study, "INTERNET," "FINDEV," "FDICAP," "GDPC," "OPEN," "EDU," and "INST" are considered endogenous variables, and "POP" is considered an exogenous variable. Although the Internet affects the path of services export diversification, in countries with a high concentration on few services export items, including those with low value added, policy makers can implement policies to expand people's access to ICT, including the Internet, to allow trading firms to benefit from vast information and ideas, and innovate. This contributes to the emergence of new services oriented toward international trade, and promote services export diversification. Similarly, this study hypothesized that domestic financial markets, education level, trade openness, size of FDI inflows, and institutional quality influence the level of a country's services export diversification. Simultaneously, to promote services export diversification, including toward modern services exports, governments can implement policies to enhance financial development and people skills, improve openness to international trade, attract FDI inflows, and institutional 
and governance quality.

Tables 2 and 3 report the outcomes associated with the estimations of different specifications of the dynamic model (1) through the two-step system GMM estimator. The regressions contain two lags of the dependent variable as regressors to meet the requirements of the two-step system

Table 2. Effect of the Internet Penetration on Services Exports Concentration Estimator: Two-Step System GMM

\begin{tabular}{|c|c|c|}
\hline VARIABLES & $\begin{array}{l}\text { HHI } \\
\text { (1) }\end{array}$ & $\begin{array}{l}\text { THEIL } \\
\text { (2) }\end{array}$ \\
\hline \multirow[t]{2}{*}{$\mathrm{HHI}_{\mathrm{t}-1}$} & $0.851 * * *$ & $0.577^{* * *}$ \\
\hline & $(0.0172)$ & $(0.0232)$ \\
\hline \multirow[t]{2}{*}{$\mathrm{HHI}_{\mathrm{t}-2}$} & $-0.0765^{* * *}$ & $-0.143 * * *$ \\
\hline & $(0.0112)$ & $(0.0187)$ \\
\hline \multirow[t]{2}{*}{ INTERNET } & $-0.142 * * *$ & $-0.215^{* * *}$ \\
\hline & $(0.0280)$ & $(0.0527)$ \\
\hline \multirow[t]{2}{*}{$\log (\mathrm{GDPC})$} & $1.631^{*}$ & -2.104 \\
\hline & $(0.939)$ & $(1.416)$ \\
\hline \multirow[t]{2}{*}{$\log (\mathrm{OPEN})$} & $0.647 * *$ & $2.440 * * *$ \\
\hline & $(0.309)$ & $(0.378)$ \\
\hline \multirow[t]{2}{*}{ FDICAP } & $-0.923 * * *$ & $0.383^{*}$ \\
\hline & $(0.130)$ & $(0.215)$ \\
\hline \multirow[t]{2}{*}{ FINDEV } & $-0.0258 * *$ & $-0.0947 * * *$ \\
\hline & $(0.0124)$ & $(0.0186)$ \\
\hline \multirow[t]{2}{*}{ EDU } & $-0.0381 * *$ & -0.0456 \\
\hline & $(0.0191)$ & $(0.0278)$ \\
\hline \multirow[t]{2}{*}{ INST } & $-0.677^{*}$ & 0.641 \\
\hline & $(0.392)$ & $(0.699)$ \\
\hline \multirow[t]{2}{*}{$\log (\mathrm{POP})$} & $-3.404 * * *$ & $-5.114 * * *$ \\
\hline & $(0.412)$ & $(0.867)$ \\
\hline \multirow[t]{2}{*}{ Constant } & $83.34 * * *$ & $180.7^{* * *}$ \\
\hline & (12.48) & (20.93) \\
\hline Observations - Countries & $379-131$ & $379-131$ \\
\hline Number of Instruments & 102 & 102 \\
\hline AR1 (P-Value) & 0.0055 & 0.0012 \\
\hline AR2 (P-Value) & 0.2891 & 0.2447 \\
\hline OID (P-Value) & 0.7507 & 0.4584 \\
\hline
\end{tabular}

(Note) $*$ p-value $<0.1 ; * *$ p-value $<0.05 ; * * *$ p-value $<0.01$. Robust standard errors are in parenthesis. In the two-step system GMM estimations, the variables "INTERNET", "GDPC", "FINDEV", "FDICAP", "OPEN", "EDU", and "INST" have been considered as endogenous. The variable "POP" has been considered as exogenous. Time dummies have been included in the regressions. Two lags of the dependent variables have been used as regressors so as to meet the requirements of the two-step system GMM estimator. This is because with only one lag of the dependent variable as a regressor, these requirements were not met. 
Table 3. Effect of the Internet Penetration on Services Exports Concentration Across Sub-Samples Estimator: Two-Step System GMM

\begin{tabular}{|c|c|c|c|c|}
\hline Variables & $\begin{array}{c}\mathrm{HHI} \\
(1)\end{array}$ & $\begin{array}{l}\text { THEIL } \\
\text { (2) }\end{array}$ & $\begin{array}{c}\mathrm{HHI} \\
(3)\end{array}$ & $\begin{array}{l}\text { THEIL } \\
\text { (4) }\end{array}$ \\
\hline $\begin{array}{l}\text { One-period lag of the } \\
\text { dependent variable }\end{array}$ & $\begin{array}{l}0.867 * * * \\
(0.0224)\end{array}$ & $\begin{array}{l}0.571 * * * \\
(0.0269)\end{array}$ & $\begin{array}{l}0.863 * * * \\
(0.0163)\end{array}$ & $\begin{array}{l}0.646^{* * *} \\
(0.0236)\end{array}$ \\
\hline $\begin{array}{c}\text { Two-period lag of the } \\
\text { dependent variable }\end{array}$ & $\begin{array}{c}-0.0959 * * * \\
(0.0167)\end{array}$ & $\begin{array}{c}-0.119 * * * \\
(0.0211)\end{array}$ & $\begin{array}{c}-0.0843 * * * \\
(0.0148)\end{array}$ & $\begin{array}{c}-0.120 * * * \\
(0.0210)\end{array}$ \\
\hline INTERNET & $\begin{array}{l}-0.155^{* * *} \\
(0.0467)\end{array}$ & $\begin{array}{l}-0.102 \\
(0.0913)\end{array}$ & $\begin{array}{c}-0.150 * * * \\
(0.0378)\end{array}$ & $\begin{array}{c}-0.136^{* * *} \\
(0.0499)\end{array}$ \\
\hline HIC*INTERNET & $\begin{array}{l}-0.0124 \\
(0.0425)\end{array}$ & $\begin{array}{l}-0.170^{* *} \\
(0.0829)\end{array}$ & & \\
\hline LDC*INTERNET & & & $\begin{array}{c}-0.457^{* * *} \\
(0.109)\end{array}$ & $\begin{array}{c}0.361 \\
(0.276)\end{array}$ \\
\hline $\mathrm{HIC}$ & $\begin{array}{c}3.674 \\
(3.009)\end{array}$ & $\begin{array}{l}-3.364 \\
(5.208)\end{array}$ & & \\
\hline LDC & & & $\begin{array}{c}9.153 * * * \\
(2.625)\end{array}$ & $\begin{array}{c}-11.04 * * * \\
(4.146)\end{array}$ \\
\hline $\log (\mathrm{GDPC})$ & $\begin{array}{c}2.122 \\
(1.404)\end{array}$ & $\begin{array}{l}-2.242 \\
(1.960)\end{array}$ & $\begin{array}{l}2.008^{*} \\
(1.206)\end{array}$ & $\begin{array}{c}-4.026^{* * *} \\
(1.445)\end{array}$ \\
\hline $\log (\mathrm{OPEN})$ & $\begin{array}{c}1.024 * * * \\
(0.349)\end{array}$ & $\begin{array}{c}2.909 * * * \\
(0.563)\end{array}$ & $\begin{array}{c}1.275^{* * *} \\
(0.333)\end{array}$ & $\begin{array}{c}1.044 \\
(0.691)\end{array}$ \\
\hline FDICAP & $\begin{array}{c}-1.029 * * * \\
(0.163)\end{array}$ & $\begin{array}{l}0.0351 \\
(0.249)\end{array}$ & $\begin{array}{c}-1.361 * * * \\
(0.146)\end{array}$ & $\begin{array}{c}0.252 \\
(0.262)\end{array}$ \\
\hline FINDEV & $\begin{array}{c}-0.0381 * * * \\
(0.0129)\end{array}$ & $\begin{array}{c}-0.104 * * * \\
(0.0206)\end{array}$ & $\begin{array}{c}-0.0499 * * * \\
(0.0136)\end{array}$ & $\begin{array}{c}-0.109 * * * \\
(0.0198)\end{array}$ \\
\hline EDU & $\begin{array}{l}-0.0456^{*} \\
(0.0241)\end{array}$ & $\begin{array}{l}-0.00834 \\
(0.0337)\end{array}$ & $\begin{array}{l}-0.0148 \\
(0.0200)\end{array}$ & $\begin{array}{l}-0.0500 \\
(0.0415)\end{array}$ \\
\hline INST & $\begin{array}{c}-1.709 * * * \\
(0.399)\end{array}$ & $\begin{array}{c}1.011 \\
(0.881)\end{array}$ & $\begin{array}{l}-0.964 * \\
(0.514)\end{array}$ & $\begin{array}{c}1.746^{* *} \\
(0.817)\end{array}$ \\
\hline $\log (\mathrm{POP})$ & $\begin{array}{c}-4.158^{* * *} \\
(0.565)\end{array}$ & $\begin{array}{c}-6.091 * * * \\
(0.949)\end{array}$ & $\begin{array}{c}-4.258 * * * \\
(0.553)\end{array}$ & $\begin{array}{c}-3.203 * * * \\
(1.118)\end{array}$ \\
\hline Constant & $\begin{array}{c}86.63 * * * \\
(17.31)\end{array}$ & $\begin{array}{c}197.4 * * * \\
(24.98)\end{array}$ & $\begin{array}{c}98.21^{* * *} \\
(18.12)\end{array}$ & $\begin{array}{c}153.3^{* * *} \\
(28.29)\end{array}$ \\
\hline Observations - Countries & $379-131$ & $379-131$ & $379-131$ & $379-131$ \\
\hline Number of Instruments & 97 & 97 & 97 & 97 \\
\hline AR1 (P-Value) & 0.0044 & 0.0014 & 0.0052 & 0.0010 \\
\hline AR2 (P-Value) & 0.3945 & 0.1693 & 0.388 & 0.1876 \\
\hline OID (P-Value) & 0.4887 & 0.3839 & 0.5917 & 0.2517 \\
\hline
\end{tabular}

(Note) ${ }^{*} \mathrm{p}$-value $<0.1 ;{ }^{*} \mathrm{p}$-value $<0.05 ;{ }^{* * *} \mathrm{p}$-value $<0.01$. Robust standard errors are in parenthesis. In the two-step system GMM estimations, the variables "INTERNET", "GDPC", "FINDEV", "FDICAP", "OPEN", "EDU", "INST" and the interaction variables have been considered as endogenous. The variable "POP" has been considered as exogenous. Time dummies have been included in the regressions. Two lags of the dependent variables have been used as regressors so as to meet the requirements of the two-step system GMM estimator. This is because with only one lag of the dependent variable as a regressor, these requirements were not met. 
GMM estimator. In fact, when model (1) or its different specifications are estimated with only one lag of the dependent variable as regressor, these requirements are not satisfied. Results in Table 1 emerge from the estimation by the FE and FGLS estimators of model (1) and where the dependent variable is, respectively, "HHI" (Table 1, column [1]) and "THEIL" (Table 1, column [2]). Table 3 presents the outcomes emerging from the estimations of other specifications of model (1), where the dependent variable is "HHI" and "THEIL," that helps examine the effect of the Internet penetration on services export diversification in high-income countries (HICs) versus Non-HICs (also referred to as developing countries, i.e., countries in the full sample that are not in the category of HICs). The subsample of HICs is taken from the World Bank's classification of countries. The effect of the Internet on services export diversification in LDCs is also examined. The subsample of LDCs is chosen because LDCs represent the poorest countries, and the most vulnerable ones to global external and environmental shocks. ${ }^{12}$ ) They exhibit a high concentration of services export on limited number of few items (WTO, 2019c). To examine the effect of the Internet penetration on services export concentration in HICs and LDCs, respectively, a dummy variable is created for each group of countries, which takes the value 1 when a country belongs to a relevant category, and 0 , otherwise. The dummies created are called HIC and LDC and refer, respectively, to the subsamples HICs and LDCs. Each of these dummies and its interaction with the variable "INTERNET" are included in model (1).

Before discussing the estimates presented in Tables 1 to 3 , it is useful to get a first view on the statistical correlation between the variable of interest, namely, the Internet penetration, and the indicators of services export diversification. Figures 1 and 2 provide the correlation patterns between these variables over the full sample and the subsamples of HICs and Non-HICs (i.e., developing countries). Figure 1 suggests a negative correlation pattern between "INTERNET" and "HHI," which indicates a positive correlation between the Internet penetration aret and services export diversification. However, the correlation pattern between "INTERNET" and "THEIL" is not distinct. Figure 2 indicates that the correlations between Internet penetration and services export concentration indices are negative for HICs, although it is higher when using "HHI" rather than "THEIL," thus suggesting that the Internet penetration rate is positively correlated with services export diversification in HICs. For developing countries, the correlation pattern between "INTERNET" and "HHI" appears to be negative, while it is positive between "INTERNET" and "THEIL." Consequently, it is difficult to conclude on the direction of the correlation pattern between the Internet penetration and services export concentration in developing countries.

12) For details on the criteria used to select countries that can be included in the group of LDCs, see information online at: http://unohrlls.org/about-ldcs/ 
Figure 1. Correlation pattern between the Internet penetration and indices of services export concentration_over the full sample
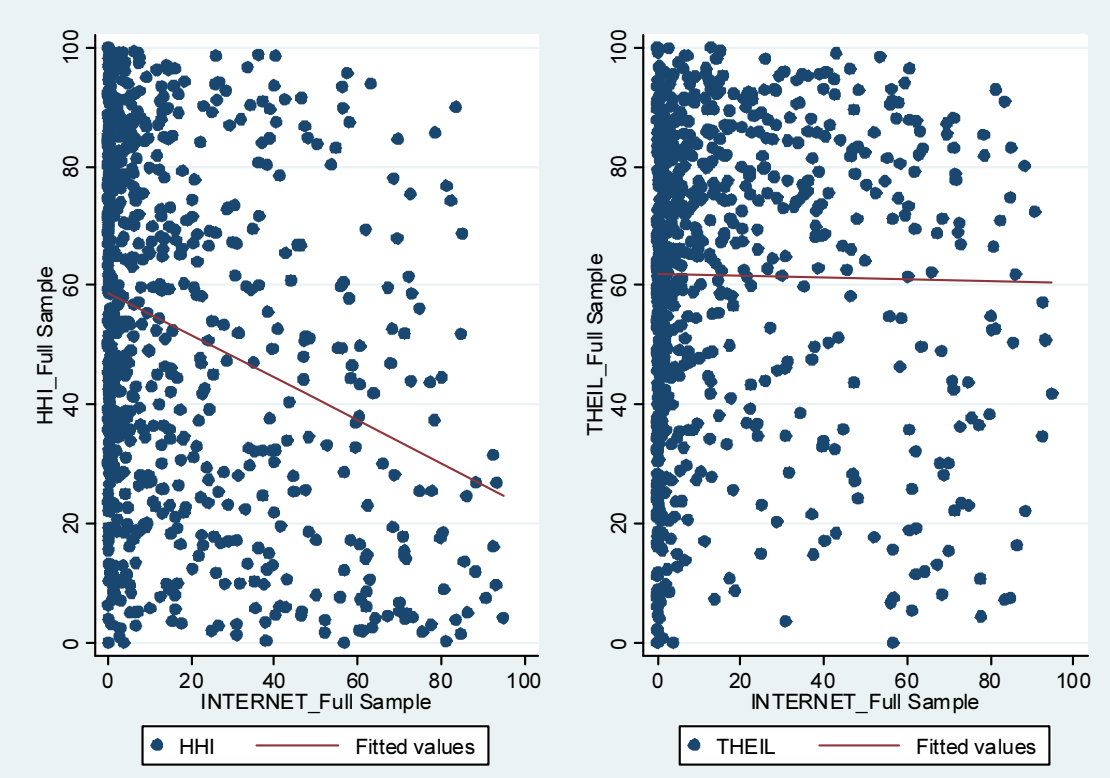

(Source) Author

Figure 2. Correlation pattern between the internet penetration and indices of services export concentration_over sub-samples of HICs and developing countries
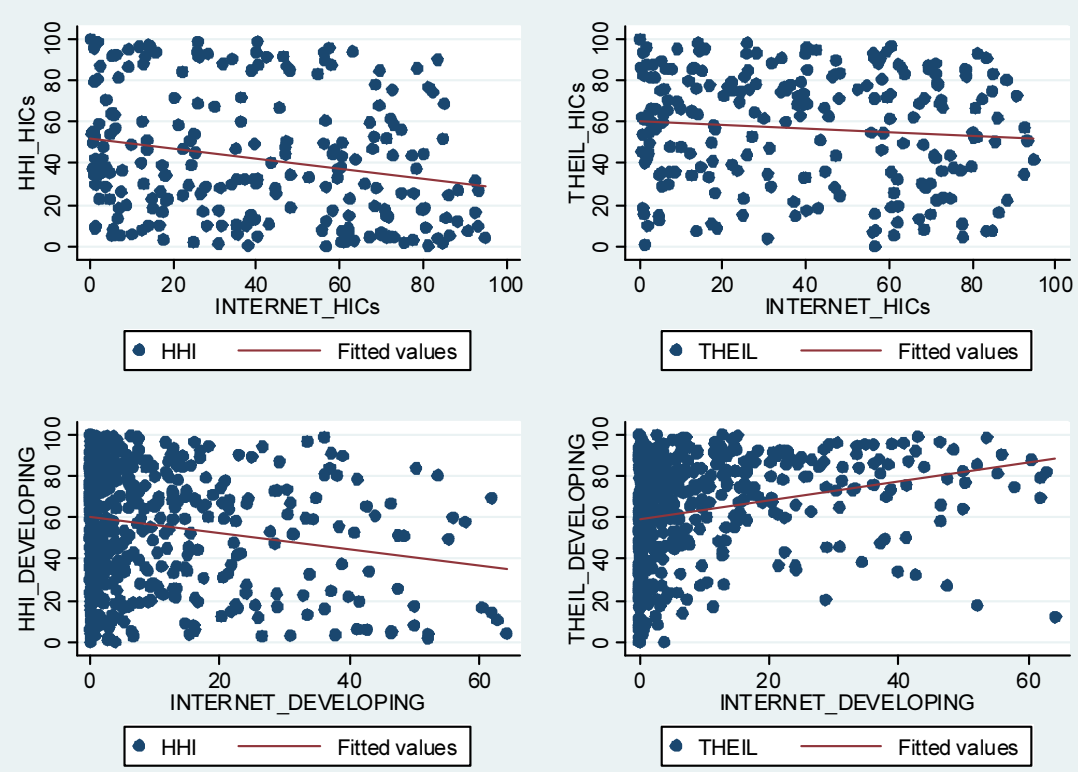

(Source) Author 


\section{Interpretation of Empirical Results}

Results based on the FE estimator (Table 1, columns [1] and [2]) show that Internet penetration has a negative and significant effect (at 1\% level) on the two indices "HHI" and "THEIL," although the absolute value of the effect is higher (nearly double) with "THEIL" than with "HHI." These two outcomes show that, regardless of the magnitude of the estimates, greater Internet penetration promotes services export diversification over the full sample. These results are confirmed considering the estimates based on the FGLS estimator and presented in column [3] for "HHI" and column [4] for "THEIL." Here, the absolute value of the magnitude of this effect is higher for "HHI" than for "THEIL" (nearly double). The coefficients of the variable "INTERNET" resulting from the estimates of the static specifications of model (1) with the HHI and based on FE and FGLS exhibit similar magnitudes (see columns [1] and [3]), while those in columns [2] and [4] exhibit different magnitudes. For control variables, across columns [1] and [2], the real per capita income is negatively and significantly associated with services export concentration, which suggests that as countries develop, they improve their level of services export diversification. The institutional and governance quality and the education level are positively and significantly associated with services export concentration. Population size is positively and significantly associated with services export concentration only for results in column [2]. Other variables, including financial development, real per capita FDI inflows, and trade openness, do not significantly (at 10\% level) affect services export concentration. In columns [3] and [4], the real per capita income and the degree of trade openness do not influence services export concentration. In addition, financial development, real per capita FDI inflows, and the population size have a positive and significant effect on services export concentration. Institutional and governance quality and education influence significantly $\mathrm{HHI}$ and THEIL only in column [3], but not in column [4].

Estimates based on the FE and FGLS estimators are possibly biased. Therefore, the outcomes in Tables 2 and 3 based on the two-step system GMM approach must be considered. Suitability of the two-step system GMM estimator is assessed by considering the outcomes of the diagnostic tests described earlier. Tables 2 and 3 show that the coefficient of the lags of the dependent variables is always statistically significant at the $1 \%$ level, thereby confirming the persistence of "HHI" and "THEIL" over time. This underlines the dynamic nature of model (1). Particularly, a rise in the index of services export concentration in periods $t-1$ induces a higher degree of services exports concentration in period $t$, whereas a rise in the index of services export concentration in period $t-2$ induces a higher degree of services export diversification in period $t$. However, Table 2 shows that the $p$-values associated with the AR(1) test are always lower than 0.01 ( $1 \%$ significance level); as expected, the $p$-values related to the AR (2) and AR(3) tests are all greater than 0.10 (i.e., the $10 \%$ significance). The $p$-values related to the OID 
test are also always greater than 0.10 ; finally, the number of countries is consistently higher than the number of instruments across all columns of the two tables. Based on these varying results, we conclude that the two-step system GMM estimator is suitable for conducting the empirical analysis. The outcomes of the estimations reported in Tables 2 and 3 can be interpreted.

Table 2 shows that Internet penetration is negatively and significantly (at $1 \%$ level) associated with services export concentration in columns [1] and [2]. This indicates that greater access to the Internet favors services export diversification over the full sample. However, the absolute value of the coefficient of the "INTERNET" variable in column [1] (result based on "HHI") is lower than that of the same variable in column [2]. In terms of magnitude, a 1 percentage point increase in the Internet penetration rate is associated with a 0.14-point decrease in the $\mathrm{HHI}$ indicator and a 0.215 -point fall in the THEIL indicator over the full sample. Interestingly, the effect of the Internet penetration on HHI is similar to that in Table 1, columns [1] and [3]. However, this effect on THEIL is different from the ones observed in Table 1, columns [2] and [4]. Concerning control variables, estimates are not always similar across the two columns of Table 2, in terms of both sign and statistical significance. Results in column [1] show that at the $5 \%$ level, the real per capita income and the institutional and governance quality do not significantly affect services export concentration, while greater trade openness is positively and significantly associated with services export concentration. Improved FDI inflows, financial development, education level, and increase in the population size are positively associated with services export diversification. Column [2] shows that, at the 5\% level, real per capita income, FDI inflows, the education level, and the institutional and governance quality do not significantly affect services export concentration. In contrast, as in column [1], greater trade openness induces a higher concentration of services exports, while financial development and the population size positively influence services export diversification.

Table 3 shows that the estimates related to control variables are consistent with those reported in column [1] of Table 2 based on "HHI," which in turn shows that the coefficient of the variable "INTERNET" is negative and significant at the $1 \%$ level. Moreover, the effect of Internet penetration on services export concentration is the same in both HICs and developing countries, because in column [1] of Table 3, the coefficient of the interaction variable "HIC*INTERNET" is not significant at the conventional levels. Thus, the estimates in column [2] of Table 3 based on "THEIL" indicate that the effect of Internet penetration on services export diversification is higher in HICs than in developing countries (the coefficient of the interaction variable "HIC*INTERNET" is significant at the 5\% level). These estimates show that a 1 percentage point increase in the Internet penetration rate is associated with a 0.155 -point decrease in the degree of services export concentration ("HHI") in both HICs and developing countries. Similarly, a 1 percentage point increase in Internet penetration rate leads to a 0.170 -point fall in the level of services export concentration ("THEIL") in HICs. Columns [3] and [4] of Table 
3 show the effect of Internet penetration on services export diversification, measured by "HHI" and "THEIL" indicators, in LDCs. Particularly, results in column [3] of Table 3 show a negative and significant coefficient (at the $1 \%$ level) of the interaction variable "LDC*INTERNET," which indicates that Internet penetration has a greater positive effect on services export diversification ("HHI") in LDCs than in other countries in the full sample. Thus, the effect of Internet penetration on services export concentration is -0.60713) $(=-0.150-0.457)$ for LDCs and -0.150 for Non-LDCs in the full sample. Therefore, a 1 percentage point increase in the Internet penetration rate is associated with a 0.607 -point decrease in the degree of services export concentration ("HHI") in LDCs, and a 0.150-point decrease in the degree of services export concentration ("HHI") in Non-LDCs. Column [4] of Table 3 suggests that the interaction term of the variable "LDC*INTERNET" is not significant at the conventional levels, while the coefficient of the variable "INTERNET" is significant at the $1 \%$ level. Based on these two outcomes, it can be deduced that the effect of Internet penetration rate on services export concentration ("THEIL") is the same in LDCs and Non-LDCs, and amounts to -0.136: a 1 percentage point increase in the Internet penetration rate is associated with a 0.136-point fall in the level of services export concentration ("THEIL") in LDCs and Non-LDCs alike.

Overall, while the results based on the indicators HHI and THEIL are not the same in terms of magnitude, sign, and statistical significance for all control variables, they show that greater access to the Internet is positively associated with services export diversification over the full sample. This outcome obtained over the full sample reflects different results over subsamples, but those results also show that greater Internet penetration rate is associated with a higher degree of services export diversification. Focusing specifically on the preferred measure of services export concentration ("HHI"), a rise in the Internet penetration rate promotes services export diversification in HICs and developing countries alike, and has a higher positive effect on services export diversification in LDCs than in other countries in the full sample.

\section{Further Analysis}

Section 2 postulated that the Internet could influence services export diversification path through its effects on innovation and goods exports as well as on export product concentration and FDI inflow channels. This section tests these hypotheses. Therefore, the study adopts the preferred estimator of services export concentration (i.e., "HHI") and estimates several variants of model (1) using the two-step system GMM estimator. For the first variant of model (1), an indicator measuring the degree of innovation along with its interaction with the variable "INTERNET"

13) This coefficient is obtained by adding the estimate associated with the variable "INTERNET" and the coefficient of the interaction variable "LDC*INTERNET." 
are introduced. The level of innovation in a given country is measured by the number of patents granted to the residents of the country by the local national patent office. This innovation variable is denoted "PATENT." Column [1] of Table 4 displays the results of the estimation of this model specification. To explore whether the effect of Internet penetration on services export concentration translates through the merchandise exports channel, two other specifications of model (1) are estimated. The first includes the variable "MERCHGR," which represents the growth rate (\%) of the total merchandise exports and its squared term (column [2], Table 4). This variant of model (1) helps in testing the existence of a nonlinear relationship ${ }^{14}$ ) between merchandise export growth and services export concentration. Finally, the second specification of model (1) introduces the variable "MERCHGR" and its interaction with "INTERNET," and the squared term of "MERCHGR" and its interaction with the variable "INTERNET." Column [3] of Table 4 displays the results of the estimation of this third specification of model (1).

Table 4. Effect of the Internet Use on Services Exports Concentration ("HHI") for Varying Levels of Innovation/Merchandise Export Growth Rates

Estimator: Two-Step System GMM

\begin{tabular}{|c|c|c|c|}
\hline Variables & $\begin{array}{c}\text { HHI } \\
\text { (1) }\end{array}$ & $\begin{array}{c}\text { HHI } \\
\text { (2) }\end{array}$ & $\begin{array}{c}\text { HHI } \\
\text { (3) }\end{array}$ \\
\hline \multirow[t]{2}{*}{$\mathrm{HHI}_{\mathrm{t}-1}$} & $0.858 * * *$ & $0.850 * * *$ & $0.831 * * *$ \\
\hline & $(0.0128)$ & $(0.0159)$ & $(0.0111)$ \\
\hline \multirow[t]{2}{*}{$\mathrm{HHI}_{\mathrm{t}-2}$} & $-0.114 * * *$ & $-0.0717 * * *$ & $-0.0762 * * *$ \\
\hline & $(0.0145)$ & $(0.0131)$ & $(0.00788)$ \\
\hline \multirow[t]{2}{*}{ INTERNET } & $-0.379 * * *$ & $-0.0851 * * *$ & $-0.197 * * *$ \\
\hline & $(0.0531)$ & $(0.0248)$ & $(0.0160)$ \\
\hline \multirow[t]{2}{*}{ INTERNET*Log(PATENT) } & $0.0543^{* * *}$ & & \\
\hline & $(0.00757)$ & & \\
\hline \multirow[t]{2}{*}{$\log ($ PATENT $)$} & $-4.455^{* * *}$ & & \\
\hline & $(0.481)$ & & \\
\hline \multirow[t]{2}{*}{ MERCHGR } & & $0.262 * * *$ & $-0.154 * * *$ \\
\hline & & $(0.0495)$ & $(0.0465)$ \\
\hline \multirow[t]{2}{*}{ MERCHGR $^{2}$} & & $-0.00108 * * *$ & $0.00374 * * *$ \\
\hline & & $(0.000275)$ & $(0.000683)$ \\
\hline \multirow[t]{2}{*}{ INTERNET*MERCHGR } & & & $0.00875^{* * *}$ \\
\hline & & & $(0.00163)$ \\
\hline \multirow[t]{2}{*}{ INTERNET*MERCHGR ${ }^{2}$} & & & $-0.000271 * * *$ \\
\hline & & & $(4.69 \mathrm{e}-05)$ \\
\hline \multirow[t]{2}{*}{$\log (\mathrm{GDPC})$} & $3.882 * * *$ & $2.876^{* * *}$ & $2.054 * * *$ \\
\hline & $(1.088)$ & $(0.598)$ & $(0.388)$ \\
\hline
\end{tabular}

14) The idea of estimating a nonlinear relationship between merchandise export growth and services export concentration arises from the observation in a graph containing the cross plot between these two variables that such a nonlinear relationship may exist (to save space, we have not presented this graph here, and it can be obtained upon request). 
Table 4. Continued

\begin{tabular}{|c|c|c|c|}
\hline Variables & $\begin{array}{c}\text { HHI } \\
\text { (1) }\end{array}$ & $\begin{array}{c}\text { HHI } \\
(2)\end{array}$ & $\begin{array}{c}\text { HHI } \\
\text { (3) }\end{array}$ \\
\hline \multirow[t]{2}{*}{$\log (\mathrm{OPEN})$} & $-1.611 * *$ & -0.0450 & 0.208 \\
\hline & $(0.652)$ & $(0.339)$ & $(0.237)$ \\
\hline \multirow[t]{2}{*}{ FDICAP } & $-0.406^{* * *}$ & $-0.999 * * *$ & $-0.494 * * *$ \\
\hline & $(0.120)$ & $(0.127)$ & $(0.0676)$ \\
\hline \multirow[t]{2}{*}{ FINDEV } & $-0.0413 * * *$ & $-0.00861 *$ & $-0.0273 * * *$ \\
\hline & $(0.00982)$ & $(0.00474)$ & $(0.00303)$ \\
\hline \multirow[t]{2}{*}{ EDU } & 0.00657 & $-0.0433 * * *$ & $-0.0211^{*}$ \\
\hline & $(0.0124)$ & $(0.0116)$ & $(0.0112)$ \\
\hline \multirow[t]{2}{*}{ INST } & 0.934 & $-1.027 * * *$ & $-1.055^{* * *}$ \\
\hline & $(0.609)$ & $(0.359)$ & $(0.230)$ \\
\hline \multirow[t]{2}{*}{$\log (\mathrm{POP})$} & $3.084 * * *$ & $-2.253 * * *$ & $-2.354 * * *$ \\
\hline & $(0.589)$ & $(0.487)$ & $(0.193)$ \\
\hline \multirow[t]{2}{*}{ Constant } & $-54.63 * * *$ & $44.96^{* * *}$ & $44.01 * * *$ \\
\hline & $(18.76)$ & $(12.41)$ & $(7.062)$ \\
\hline Observations - Countries & $238-88$ & $379-131$ & $379-131$ \\
\hline Number of Instruments & 78 & 108 & 125 \\
\hline AR1 (P-Value) & 0.0354 & 0.0059 & 0.0057 \\
\hline AR2 (P-Value) & 0.3528 & 0.2694 & 0.2975 \\
\hline OID (P-Value) & 0.3797 & 0.5953 & 0.5189 \\
\hline
\end{tabular}

(Note) $*$ p-value $<0.1 ; * *$ p-value $<0.05 ; * * *$-value $<0.01$. Robust standard errors are in parenthesis. In the two-step system GMM estimations, the variables "INTERNET", "PATENT", "MERCHGR", "GDPC", "FINDEV", "FDICAP", "OPEN", "EDU", "INST" and the interaction variables have been considered as endogenous. The variable "POP" has been considered as exogenous. Time dummies have been included in the regressions. Two lags of the dependent variables have been used as regressors so as to meet the requirements of the two-step system GMM estimator. This is because with only one lag of the dependent variable as a regressor, these requirements were not met.

We complement the analysis on whether the effect of Internet penetration on services export concentration translates through merchandise exports by investigating whether this effect passes through the export product concentration (or diversification) channel. Therefore, we use the indicator of export product concentration (denoted "PRODCONC") computed by the IMF using the Theil index (Appendix 1). Higher values of this index imply greater export product concentration, while lower values indicate greater export product diversification. To ensure consistency in the measure of export (product and services) diversification used in the study, the Theil index indicator ("THEIL") was used as a dependent variable in the specifications of model (1), in which the variable "PRODCONC" is included. Similar to Table 4 for the variable "MERCHGR," a nonlinear relation between export product diversification and services export diversification is verified by including both "PRODCONC" and its squared term in model (1). However, no such evidence was found of the existence of a nonlinear effect. Therefore, a variant of model (1) (with "THEIL" as the dependent variable) is considered in which the indicator "PRODCONC" and its interaction with the variable "INTERNET" is introduced. Column [1] of Table 5 shows 
Table 5. Effect of the Internet Use on Services Exports Concentration for Varying Levels Of Export Product Concentration/Size of FDI Inflows

Estimator: Two-Step System GMM

\begin{tabular}{|c|c|c|c|}
\hline Variables & $\begin{array}{l}\text { THEIL } \\
\text { (1) }\end{array}$ & $\begin{array}{l}\text { THEIL } \\
\text { (2) }\end{array}$ & $\begin{array}{c}\mathrm{HHI} \\
(3)\end{array}$ \\
\hline $\begin{array}{l}\text { One-period lag of the } \\
\text { dependent variable }\end{array}$ & $\begin{array}{l}0.602 * * * \\
(0.0227)\end{array}$ & $\begin{array}{l}0.550 * * * \\
(0.0123)\end{array}$ & $\begin{array}{l}0.941 * * * \\
(0.0304)\end{array}$ \\
\hline $\begin{array}{c}\text { Two-period lag of the } \\
\text { dependent variable }\end{array}$ & $\begin{array}{l}-0.118^{* * *} \\
(0.0212)\end{array}$ & $\begin{array}{l}-0.155 * * * \\
(0.00856)\end{array}$ & $\begin{array}{c}-0.0967 * * * \\
(0.0245)\end{array}$ \\
\hline INTERNET & $\begin{array}{l}-0.179 * * * \\
(0.0578)\end{array}$ & $\begin{array}{c}-0.464 * * * \\
(0.0351)\end{array}$ & $\begin{array}{c}-0.571 * * * \\
(0.0988)\end{array}$ \\
\hline PRODCONC & $\begin{array}{c}2.556 * * * \\
(0.929)\end{array}$ & $\begin{array}{c}-3.268^{* * *} \\
(0.496)\end{array}$ & \\
\hline INTERNET*PRODCONC & & $\begin{array}{c}0.0677 * * * \\
(0.00935)\end{array}$ & \\
\hline INTERNET*FDICAP & & & $\begin{array}{l}0.0411^{* * *} \\
(0.00634)\end{array}$ \\
\hline $\log (\mathrm{GDPC})$ & $\begin{array}{c}-5.552^{* * *} \\
(1.663)\end{array}$ & $\begin{array}{c}-3.457 * * * \\
(0.792)\end{array}$ & $\begin{array}{c}1.521 \\
(1.437)\end{array}$ \\
\hline $\log (\mathrm{OPEN})$ & $\begin{array}{c}2.734 * * * \\
(0.546)\end{array}$ & $\begin{array}{c}2.924 * * * \\
(0.195)\end{array}$ & $\begin{array}{l}1.140 * * \\
(0.501)\end{array}$ \\
\hline FDICAP & $\begin{array}{l}0.0743 \\
(0.257)\end{array}$ & $\begin{array}{l}-0.0906 \\
(0.0830)\end{array}$ & $\begin{array}{c}-1.529 * * * \\
(0.235)\end{array}$ \\
\hline FINDEV & $\begin{array}{c}-0.124 * * * \\
(0.0198)\end{array}$ & $\begin{array}{c}-0.0968 * * * \\
(0.0103)\end{array}$ & $\begin{array}{l}-0.0306 \\
(0.0240)\end{array}$ \\
\hline EDU & $\begin{array}{c}0.0422 \\
(0.0326)\end{array}$ & $\begin{array}{l}-0.0190 \\
(0.0174)\end{array}$ & $\begin{array}{l}-0.00168 \\
(0.0233)\end{array}$ \\
\hline INST & $\begin{array}{l}1.737 * * \\
(0.783)\end{array}$ & $\begin{array}{c}1.214 * * * \\
(0.403)\end{array}$ & $\begin{array}{l}-1.699 * * \\
(0.688)\end{array}$ \\
\hline $\log (\mathrm{POP})$ & $\begin{array}{c}-4.146^{* * *} \\
(0.954)\end{array}$ & $\begin{array}{c}-6.055 * * * \\
(0.347)\end{array}$ & $\begin{array}{c}-3.304 * * * \\
(0.925)\end{array}$ \\
\hline Constant & $\begin{array}{c}169.5 * * * \\
(24.98)\end{array}$ & $\begin{array}{c}225.4^{* * * *} \\
(8.896)\end{array}$ & $\begin{array}{c}80.31 * * * \\
(24.14)\end{array}$ \\
\hline Observations - Countries & $379-131$ & $379-131$ & $379-131$ \\
\hline Number of Instruments & 97 & 125 & 73 \\
\hline AR1 (P-Value) & 0.0012 & 0.0014 & 0.0081 \\
\hline AR2 (P-Value) & 0.2483 & 0.2974 & 0.5326 \\
\hline OID (P-Value) & 0.4199 & 0.5163 & 0.6811 \\
\hline
\end{tabular}

(Note) $*$ p-value $<0.1 ; * *$ p-value $<0.05 ; * * *$ p-value $<0.01$. Robust standard errors are in parenthesis. In the two-step system GMM estimations, the variables "INTERNET", "GDPC", "FINDEV", "FDICAP", "PRODCONC", "OPEN", "EDU", "INST" and the interaction variables have been considered as endogenous. The variable "POP" has been considered as exogenous. Time dummies have been included in the regressions. Two lags of the dependent variables have been used as regressors so as to meet the requirements of the two-step system GMM estimator. This is because with only one lag of the dependent variable as a regressor, these requirements were not met. 
that the outcomes of the estimation of the variant of model (1) that includes the variable "PRODCONC," and column [2] of Table 5 shows that the results of the estimation of the specification of model (1) that includes the variables "PRODCONC" and its interaction with the variable "INTERNET." Finally, the extent to which the effect of the Internet penetration on services export concentration passes through the FDI inflows channel is empirically examined by estimating a specification of model (1) in which the Internet penetration variable and the variable measuring FDI inflows are interacted. The results of this estimation are reported in column [3] of Table 5. The analysis uses the primary dependent variable "HHI" to build this specification of model (1), although similar results are obtained when the "THEIL" index is used alternatively as the dependent variable (results based on this index of services export product concentration could be obtained upon request).

With regard to the estimates in Tables 4 and 5, we first observe across all three columns that the requirements for the consistency of the two-step system GMM approach are met. Furthermore, the coefficients of the two lags of the dependent variable "HHI" (and "THEIL" in columns [1] and [2] of Table 5) are consistent with those obtained in the previous tables.

The outcomes ${ }^{15)}$ reported in column [1] of Table 4 show that the coefficient of the interaction variable "[INTERNET* $\log (\mathrm{PATENT})] "$ is positive and significant at the $1 \%$ level, whereas the coefficient of "INTERNET" is negative as well as significant at the $1 \%$ level. Therefore, there is a positive and significant effect of the Internet penetration rate on services export concentration once the level of innovation exceeds a threshold; otherwise (i.e., below this turning point), the Internet penetration rate is negatively associated with services export diversification. The number of patents granted beyond which the effect of Internet penetration on services export concentration changes sign is 1075 (= exponential (0.379/0.0543)) (according to descriptive statistics reported in Appendix 3, the number of patents in the full sample ranges between 1 and 121306). Hence, for countries whose number of patents granted to residents is lower than 1075 (this is likely the case for developing countries, notably LDCs), an increase in the Internet penetration rate is associated with a higher degree of services export diversification. In contrast, a greater Internet penetration rate is positively associated with services export concentration in countries that significantly innovate, that is, those with a number of patents granted to residents higher than 1075. This indicates that as countries improve innovation, they increase their level of services export concentration (possibly on sophisticated services export items). For a better understanding of these effects, Figure 3 shows that, at $95 \%$ confidence intervals, ${ }^{16)}$ an increase in the marginal impact of the Internet penetration on services export

15) Note that we have tested but not found the existence of a non-linear relationship between innovation and services export concentration (we have included both the variable "PATENT" and its squared term in model (1)).

16) The marginal impacts that are statistically significant at the $95 \%$ confidence intervals are those including only the upper and lower bounds of the confidence interval that are either above or below the zero line. 
Figure 3. Marginal impact of "INTERNET" on "HHI", for varying levels of "PATENT"

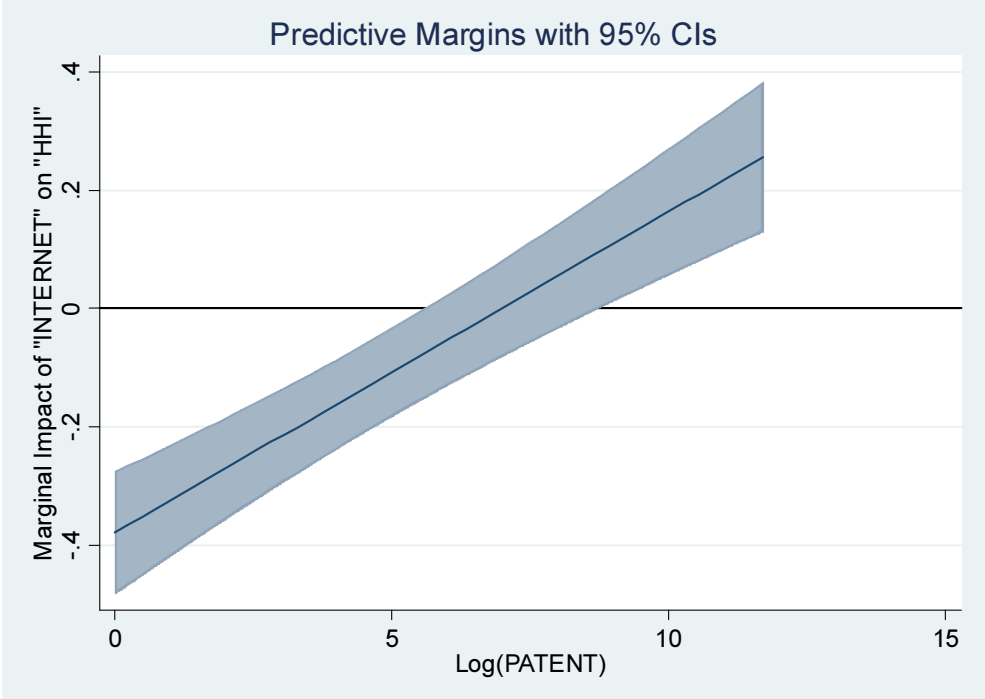

(Source) Author

concentration for varying levels of innovation, that is, for varying numbers of patents granted to countries' residents. Figure 3 shows that the marginal impact of the Internet penetration on services export concentration can take positive or negative values, but increases as countries experience increasing number of patents granted to residents. Additionally, this marginal impact is not always statistically significant at the $5 \%$ level. These outcomes confirm the finding that as countries further innovate, they increase their level of services export concentration. In particular, when the number ${ }^{17)}$ of patents is between 276 (= exponential (5.618912)) and 5782 (= exponential (8.66249)), there is no significant effect of the Internet penetration rate on services export concentration. However, in countries where the number of patents is higher than 5782, the Internet penetration influences positively and significantly services export concentration. The higher the number of patents granted, the greater is the magnitude of the enhancing effect of Internet penetration rate on services export concentration. However, countries with the number of patents fewer than 276 experience a positive and significant effect of the Internet penetration rate on services export diversification. In other words, for this latter set of countries, the rise in the Internet penetration rate is positively associated with services export diversification, and the lower the number of patents granted to residents, the greater is the magnitude of the positive effect of the Internet penetration on services export diversification. Overall, these findings indicate that greater access to the Internet promotes services export diversification in countries that have a low level of innovation (i.e., with a number of patents granted to residents lower

17) The numbers 5.618912 and 8.66249 are extracted from the Stata software when constructing the graph in Figure 3. 
than 276). However, greater Internet access is complementary with innovation in promoting services export concentration in countries that experience a relatively high level of innovation, in particular where the number of patents granted to residents is higher than 5782 .

Results in columns [2] and [3] of Table 4 show that in column [2], the variable "MERCHGR" and its squared term hold positive and negative coefficients, respectively, which are significant at the $1 \%$ level. Therefore, there exists a nonlinear relationship in the form of an inverted $\mathrm{U}$ shape between merchandise export growth and services export concentration: countries experience greater services export diversification as merchandise exports growth rate increases. This highlights the need for considering a nonlinear relationship between merchandise exports and services export concentration when examining how much the effect of the Internet penetration on services export concentration depends on countries' merchandise export growth rates. Results in column [3] of Table 4 show that the coefficients of the variables "MERCHGR" and its squared term are, respectively, negative and positive and significant at the $1 \%$ level. Concurrently, the interaction term related to the interaction variable "INTERNET*MERCHGR" is positive and significant at the $1 \%$ level, whereas the coefficient of the variable "[INTERNET*MERCHGR $\left.{ }^{2}\right]$ " is negative and significant at the $1 \%$ level. It is difficult to interpret these results taken together. Therefore, a graphical analysis is presented in Figure 4, at the $95 \%$ confidence intervals, on the marginal impact of Internet penetration on services export concentration for varying rates of the merchandise exports growth. Figure 4 shows a nonlinear relationship between Internet penetration and services export concentration for varying rates of merchandise exports growth.

Figure 4. Marginal impact of "INTERNET" on "HHI", for varying levels of "MERCHGR"

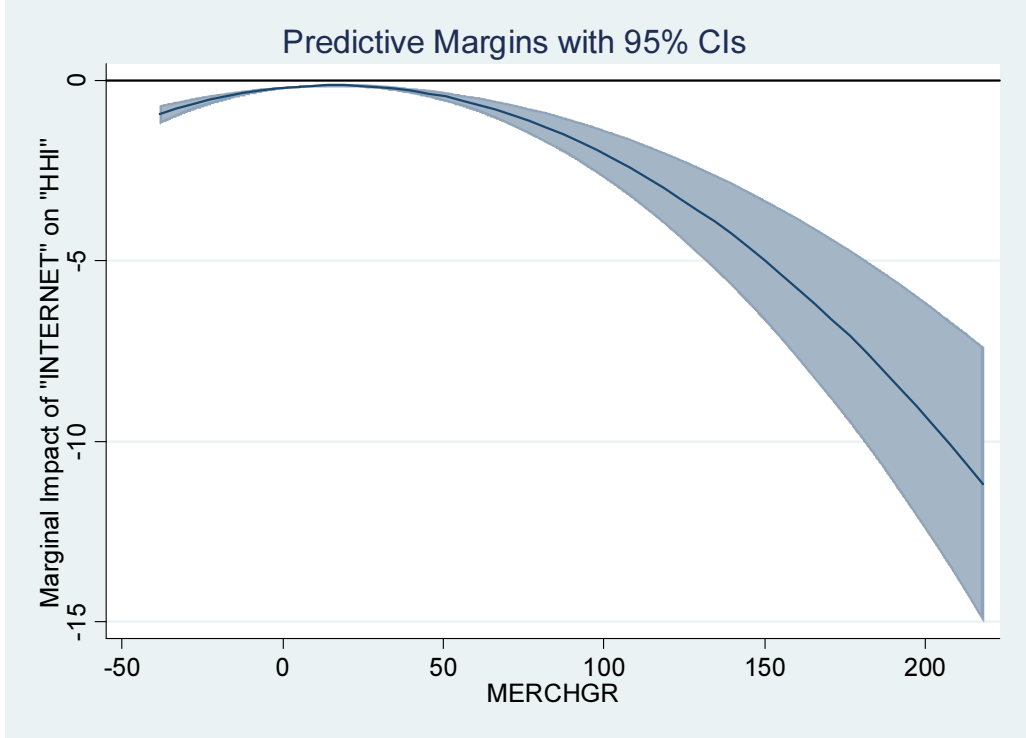

(Source) Author 
Additionally, values of the marginal impacts are all negative, which indicates that the positive impact of Internet penetration on services export diversification increases as countries experience a higher growth rate of merchandise exports, particularly when this growth rate is positive. These findings confirm the theoretical hypothesis that Internet penetration promotes services export diversification through merchandise exports channel.

Results in Table 5 show that, in column [1], export product concentration is positively and significantly (at 1\% level) associated with services export concentration. Results in column [2] in Table 5 indicate that the coefficients of variables "INTERNET" and "INTERNET*PRODCONC" are, respectively, negative and positive and significant at $1 \%$ level. These suggest that their level of export product concentration increases, particularly above the threshold value of 6.85 $(=0.464 / 0.0677)$, countries benefit from the positive effect of Internet penetration on services export concentration. Meanwhile, for levels of export product concentration lower than the threshold 6.85, the Internet penetration induces greater services export diversification. However, 6.85 is higher than the maximum value of the variable "PRODCONC," which is 6.3 (Appendix $3)$. Therefore, on average, over the full sample, Internet penetration is consistently associated with greater services export concentration as countries experience higher services exports concentration. Figure 5 shows, at the $95 \%$ confidence intervals, the marginal impact of the Internet penetration on services export concentration for varying levels of export product concentration. This marginal impact is always negative, and increases as countries experience a higher level of export product concentration. However, it is not statistically significant for

Figure 5. Marginal impact of "INTERNET" on "THEIL" for varying levels of "PRODCONC"

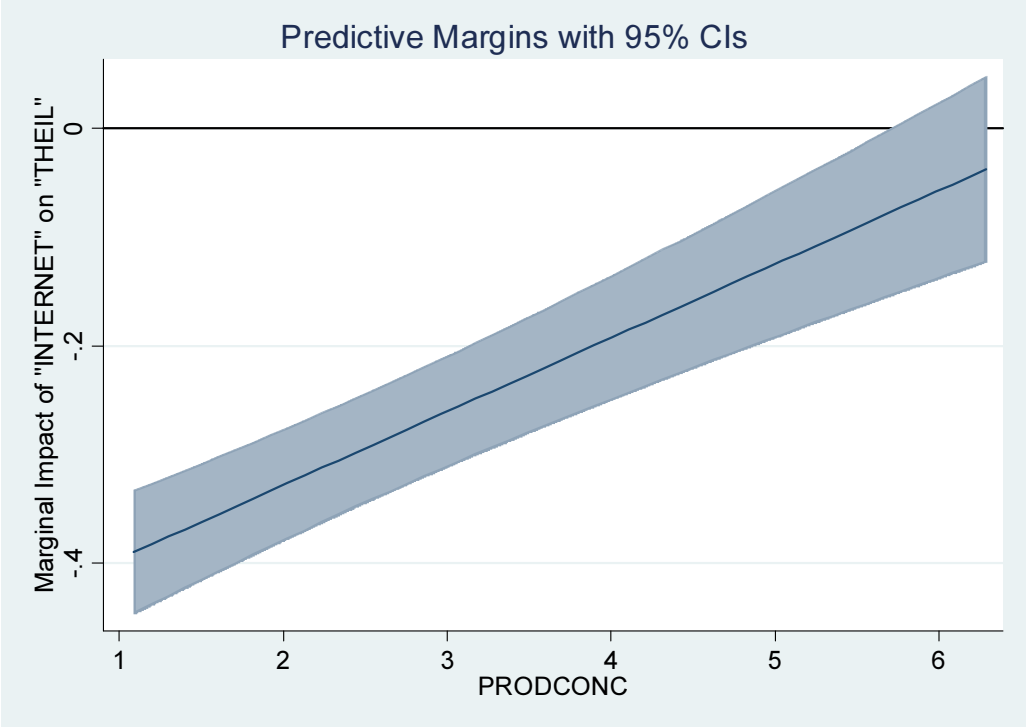

(Source) Author 
values of "PRODCONC" higher than 5.77. Therefore, given that the level of export product concentration is below the value 5.77, Internet penetration induces greater services export diversification, regardless of the degree of export product concentration. However, the positive effect of the Internet penetration on services export diversification decreases as the degree of export product concentration rises. Therefore, as observed in column [1] of Table 5, export product concentration positively and significantly influences services export product concentration; however, in the context of higher Internet penetration rate, countries diversify their services export basket when they experience lower export product concentration (i.e., a higher degree of export product diversification).

Results in column [3] show similar patterns to those in column [2]. A negative and significant (at the 1\% level) estimate of the variable "INTERNET," and a positive and significant (at the $1 \%$ level) coefficient of the interaction variable "INTERNET*FDICAP" are obtained. Therefore, countries consistently enjoy a positive effect of the Internet penetration on services export diversification as they experience an increase in the size of per capita FDI inflows. However, the magnitude of this positive effect of the Internet penetration on services export diversification decreases as the size of FDI inflows increases. This shows that as FDI flows into countries, the latter use greater Internet access to improve their services exports concentration on relatively few items, possibly highly sophisticated items. In contrast, in countries with low FDI inflows, the Internet access is complementary with FDI inflows in promoting services export diversification.

Figure 6. Marginal impact of "INTERNET" on "THEIL" for varying size of FDI inflows

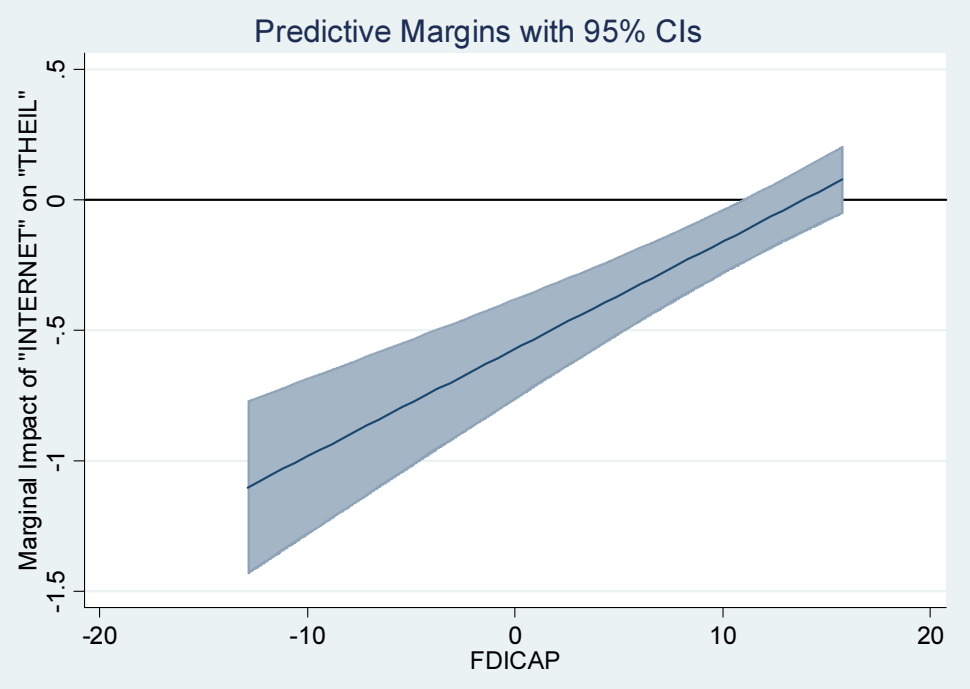

(Source) Author 


\section{Conclusion}

This study examines the effect of Internet access on services export diversification using a sample of 131 countries of both developed and developing countries during 1995-2014. The analysis, which is mainly based on the two-step system GMM technique, shows for the full sample that a rise in the Internet penetration rate induces greater services export diversification. This finding applies to the subsamples of HICs and developing countries, particularly LDCs among the developing countries. Interestingly, the study shows that the effect of Internet penetration on services export diversification translates through the innovation and merchandise exports channels. Specifically, the findings show that greater access to the Internet consistently promotes services export diversification in countries enjoying a higher merchandise export growth. However, Internet penetration complements innovation in promoting services export diversification in countries with very low levels of innovation, but complements innovation in promoting services export concentration in countries with a high degree of innovation. However, greater access to the Internet promotes services export diversification in countries experiencing greater export product concentration. Furthermore, countries receiving lower FDI inflows tend to diversify their services export items.

The world has entered into the so-called fourth industrial revolution where the ICT, in particular the Internet, has been progressively shaping all economic activities. Compared with the traditional manufacturing sector, the services sector has been increasingly contributing to economic growth and development in developed and developing countries alike. This is particularly the case for LDCs whose exports heavily depend on primary commodities and those exploring other alternatives modes of development, including that based on the services sector. This study provides the policy implication that policies for promoting access to the Internet would help countries diversify services exports items. Therefore, the international community should focus on LDCs, given their limited resources for increasing investments in digital infrastructure and, developing and implementing policies to help leverage the progress of Internet access so as to promote diversification of services exports.

This study relates to the effect of Internet penetration (one proxy for ICT development) on services export diversification. The relationship between ICT development and services export diversification can be an avenue for future research although, as noted by Clark (2008), the Internet penetration rate is a good proxy for the more global investment in information and technology. 


\section{References}

Abeliansky, A. L., \& Hilbert, M. (2017). Digital technology and international trade: Is it the quantity of subscriptions or the quality of data speed that matters? Telecommunications Policy, 41(1), 35-48.

Acs, Z. J., Audretsch, D. B., \& Feldman, M. P. (1994). R\&D spillovers and recipient firm size. The Review of Economics and Statistics, 76(2), 336-340.

Aditya, A., \& Acharyya, R. (2015). Trade liberalization and export diversification. International Review of Economics and Finance, 39, 390-410.

Adlung, R. (2007). The Contribution of Services Liberalization to Poverty Reduction: What Role for the GATS? (Staff Working Paper ERSD-2007-01), World Trade Organization, Geneva.

Agosin, M. R., Alvarez, R., \& Bravo-Ortega, C. (2012). Determinants of export diversification around the world: 1962-2000. The World Economy, 35(3), 295-315.

Ali, M. (2017). Determinants of related and unrelated export diversification. Economies, 5(4), 50.

Amighini, A., \& Sanfilippo, M. (2014). Impact of South-South FDI and trade on the export upgrading of African economies. World Development, 64, 1-17.

Anand, R., Mishra, S., \& Spatafora, N. (2012). Structural transformation and the sophistication of production (IMF working paper. WP/12/59). International Monetary Fund, Washington, DC.

Ansari, M. I., \& Ojemakinde, A. (2003). Explaining asymmetry in the US merchandise and service account balance: Does the service Sector Hold the key to the US current account woes? The International Trade Journal, 17(1), 51-80.

Arellano, M., \& Bond, S. (1991). Some tests of specification for panel data: Monte Carlo evidence and an application to employment equations. Review of Economic Studies, 58(2), 277-297.

Arellano, M., \& Bover, O. (1995). Another look at the instrumental variable estimation of error-components models. Journal of Econometrics, 68(1), 29-51.

Arthur, W. B. (2007). The structure of invention. Research Policy, 36(2), 274-287.

Bahar, D., \& Santos, M. A. (2018). One more resource curse: Dutch disease and export concentration. Journal of Development Economics, 132, 102-114.

Balchin, N., Hoekman, B., Martin, H., Mendez-Parra, M., Papadavid, P., Primack, D., \& Willem te Velde, D. (2016). Trade in services and economic transformation. DFID or ODI, United Kingdom. Southeastern Europe. Retrieved from https://cadmus.eui.eu/bitstream/handle/1814/44716/Trade-in-Services-and-Eco nomic-Transformation_Final-Nov2016.pdf?sequence $=1$ \&isAllowed $=\mathrm{y}$

Baldwin, R., Forslid, R., \& Ito, T. (2015). Unveiling the evolving sources of value added in exports. Joint Research Program Series No. 161, Institute of Developing Economies. Retrieved from https://www.ide. go.jp/library/English/Publish/Download/Jrp/pdf/161.pdf

Beck, T., Demirgüç-Kunt, A., \& Levine, R. (2000). A New Database on the Structure and Development of the Financial Sector. World Bank Economic Review, 14(3), 597-605.

Beck, T., Demirgüç-Kunt, A., \& Levine, R. (2009). Financial Institutions and Markets Across Countries and over, Data and Analysis, Time. (World Bank Policy Research Working Paper 4943). Washington, D.C.

Bianchi, C., \& mathews, S. (2016). Internet marketing and export market growth in Chile. Journal of Business Research, 69(2), 426-434. 
Blundell, R., \& Bond, S. (1998). Initial conditions and moment restrictions in Dynamic Panel Data Models. Journal of Econometrics, 87(1), 115-143.

Bowsher, C. G. (2002). On testing overidentifying restrictions in dynamic panel data models. Economics Letters, 77(2), 211-220.

Broussolle, D. (2012). A note on the links between manufacturing, goods and services exports. Amfiteatru Economic, 14(6), 600-620.

Cadot, O., Carrère, C., \& Strauss-Kahn, V. (2011). Export diversification: What's behind the hump? Review of Economics and Statistics, 93(2), 590-605.

Ceglowski, J. (2006). Does gravity matter in a service economy? Review of World Economics, 142(2), 307-329.

Chen, W.-C. (2013). The extensive and intensive margins of exports: The role of innovation. The World Economy, 36(5), 607-635.

Chitgupi, A. (2019). Macroeconomic Determinants of Software Services Exports and Impact on External Stabilisation for India: An Empirical Analysis (Working Paper No. 432). Institute for Social and Economic Change, Bangalore, India.

Choi, C. (2003). Does the Internet stimulate inward foreign direct investment? Journal of Policy Modeling, 25(4), 319-326.

Choi, C. (2010). The effect of the Internet on service trade. Economics Letters, 109(2), 102-104.

Čihák, M., Demirgüç-Kunt, A., Feyen, E., \& Levine, R. (2012). Benchmarking Financial Development Around the World (Policy Research Working Paper No. 6175). World Bank, Washington, DC.

Clarke, G. R. G. (2008). Has the internet increased exports for firms from low and middle-income countries? Information Economics and Policy, 20(1), 16-37.

Clarke, G. R. G., \& Wallsten, S. J. (2006). Has the Internet increased trade? Developed and developing country evidence. Economic Inquiry, 44(3), 465-484.

Coe, D. T., \& Helpman, E. (1995). International R and D spillovers. European Economic Review, 39(5), 859-887.

Cohen, W. M. (2010). Fifty years of empirical studies of innovative activity and performance. Handbook of the Economics of Innovation, 1, 129-213.

Costas, A., \& Demidova, S. (2008). Endogenous Variety and the Gains from Trade. American Economic Review, 98(2), 444-450.

Dash, R. K., \& Parida, P. C. (2013). FDI, services trade and economic growth in India: Empirical evidence on causal links. Empirical Economics, 45(1), 217-238.

Deardorff, A. V. (2001). International provision of trade services, trade, and fragmentation. Review of International Economics, 9(2), 233-248.

Dennis, A., \& Shepherd, B. (2011). Trade facilitation and export diversification. The World Economy, 34(1), 101-122.

Dollar, D. (1986). Technological innovation, capital mobility, and the product cycle in North-South trade. The American Economic Review, 76(1), 177-190.

Eichengreen, B., \& Gupta, P. (2013a). Exports of services: Indian experience in perspective. Indian Growth and Development Review, 6(1), 35-60.

Eichengreen, B., \& Gupta, P. (2013b). The Real Exchange Rate and Export Growth Are Services Different? (World Bank Policy Research Working Paper No. 6629). World Bank, Washington, DC. 
El Khoury, A. C., \& Savvides, A. (2006). Openness in services trade and economic growth. Economics Letters, 92(2), 277-283.

Faruq, H. A. (2011). How institutions affect export quality. Economic Systems, 35(4), 586-606.

Fernandes, A. M., Mattoo, A., Nguyen, H., \& Schiffbauer, M. (2019). The Internet and Chinese exports in the pre-Ali Baba era. Journal of Development Economics, 138, 57-76.

Fernandes, A. M., \& Paunov, C. (2012). Foreign direct investment in services and manufacturing productivity: Evidence for Chile. Journal of Development Economics, 97(2), 305-321.

Fink, C., Mattoo, A., \& Neagu, I. C. (2005). Assessing the impact of communication costs on international trade. Journal of International Economics, 67(2), 428-445.

Fiorini, M., \& Hoekman, B. (2018). Restrictiveness of Services Trade Policy and the Sustainable Development Goals (ADBI Working Paper No. 903). Asian Development Bank Institute, Tokyo.

François, J., \& Hoekman, B. (2010). Services trade and policy. Journal of Economic Literature, 48(3), 642-692.

François, J., \& Reinert, K. (1996). The role of services in the structure of production and trade: Stylized facts from cross-country analysis. Asia-Pacific Economic Review, 2(1), 35-45.

Freund, C. L., \& Weinhold, D. (2004). The effect of the Internet on international trade. Journal of International Economics, 62(1), 171-189.

Freund, C., \& Weinhold, D. (2002). The internet and international trade in services. American Economic Review, 92(2), 236-240.

Gani, A., \& Clemes, M. D. (2013). Modeling the effect of the domestic business environment on services trade. Economic Modelling, 35, 297-304.

Ghani, E., \& Kharas, H. (2010). The service revolution overview. In E. Ghani (Ed.), The Service Revolution in South Asia (pp. 1-34). Oxford: Oxford University Press.

Gnangnon, S. K. (2019a). Aid for trade and export diversification in recipient-countries. The World Economy, 42(2), 396-418.

Gnangnon, S. K. (2019b). Does the Impact of Aid for Trade on Export Product Diversification depend on Structural economic policies in Recipient-Countries? Economic Issues, 24(1), 59-87.

Gnangnon, S. K. (2019). Export Product Diversification, Trade Openness and Foreign Direct Investment Inflows: An Empirical Analysis. Asian Development Perspectives, 10(2), 114-134.

Gnangnon, S. K., \& Iyer, H. (2018). Does bridging the Internet Access Divide contribute to enhancing countries' Integration into the Global Trade in Services Markets? Telecommunications Policy, 42(1), 61-77.

Goswami, A. G., Gupta, P., \& Mattoo, A. (2012). Chapter 3. 'A cross-country analysis of service exports: Lessons from India'. In A. G. Goswami, Mattoo, A., and Sáez, S. (eds.), Exporting Services-A Developing Country Perspective. International Bank for Reconstruction and Development/International Development Association or The World Bank, Washington D. C.

Grossman, G. M., \& Helpman, E. (1989). Product development and international trade. Journal of Political Economy, 97(6), 1261-1283.

Grossman, G. M., \& Helpman, E. (1991). Innovation and Growth in the Global Economy. MIT Press, Cambridge, MA.

Grünfeld, L. A., \& Moxnes, A. (2003). The Intangible Globalization: Explaining the Patterns of International 
Trade in Services. Discussion Paper 657. Norwegian institute of international discussion Paper 657, Norwegian Institute of International Affairs, Oslo.

Harding, T., \& Javorcik, B. S. (2012). Foreign direct investment and export upgrading. Review of Economics and Statistics, 94(4), 964-980.

Hausmann, R., Hwang, J., \& Rodrik, D. (2007). What you export matters. Journal of Economic Growth, $12(1), 1-25$.

Helpman, E., \& Krugman, P. J. (1985). Market Structure and Foreign Trade. MIT, Cambridge, MA. Herzer, D. (2011). The Long-run Relationship between Outward Foreign Direct Investment and Total Factor Productivity: Evidence for Developing Countries. Journal of Development Studies, 47(5), 767-785.

Hoekman, B. (2017). Trade in Services - Opening Markets to Create Opportunities (UNU-WIDER Working Paper 2017/31). United Nations University World Institute for Development Economics Research, Helsinki, Finland.

Hoekman, B., \& Braga, C. A. P. (1997). Protection and trade in services: A survey. Open Economies Review, $8(3), 285-308$.

Hoekman, B., \& Mattoo, A. (2008). Services Trade and Growth (Policy Research Working Paper No. 4461). World Bank, Washington, DC.

Hoekman, B., \& Shepherd, B. (2017). Services Productivity, Trade Policy and Manufacturing Exports. World Economy, 40(3), 499-516.

Huang, J. H., \& Viana, S. (1995). Modelling US services trade flows: A Cointegration-ECM approach (Federal Reserve Bank of New York Research Paper, No. 9518).

Ibrahim, M., Adam, I. O., \& Sare, Y. A. (2019). Networking for foreign direct investment in Africa: How important are ICT Environment and Financial Sector Development? Journal of Economic Integration, 34(2), 346-369.

Imbs, J., \& Wacziarg, R. (2003). Stages of diversification. American Economic Review, 93(1), 63-86.

Jensen, R. (2007). The digital provide: Information (technology), market performance, and welfare in the South Indian fisheries sector. The Quarterly Journal of Economics, 122(3), 879-924.

Kandilov, I. T., \& Grennes, T. (2010). The determinants of service exports from Central and Eastern Europe. Economics of Transition, 18(4), 763-794.

Karam, F., \& Zaki, C. (2013). On the determinants of trade in services: Evidence from the MENA region. Applied Economics, 45(33), 4662-4676.

Karmali, D. P., \& Sudarsan, P. K. (2008). Impact of trade in goods on trade in services: A country level panel data analysis. Indian Journal of Economics and Business, 7(1), 145-154.

Kaufmann, D., Kraay, A., \& Mastruzzi, M. (2010). The Worldwide Governance Indicators Methodology and Analytical Issues. World Bank Policy Research 5430, Washington, DC (WPS5430).

Kim, Y. R. (2019). Does aid for trade diversify the export structure of recipient countries? World Economy, 42(9), 2684-2722.

Kimura, F., \& Lee, H. H. (2006). The gravity equation in international trade in services. Review of World Economics, 142(1), 92-121.

Klepper, S., \& Simons, K. L. (2005). Industry shakeouts and technological change. International Journal of Industrial Organization, 23(1-2), 23-43. 
Krugman, P. (1979). A model of innovation, technology transfer, and the world distribution of income. Journal of Political Economy, 87(2), 253-266.

Krugman, P. R. (1981). Intra-industry specialization and gains from trade. Journal of Political Economy, 89(7), 959-973.

Krugman, P., \& Venables, A. J. (1990). Integration and the competitiveness of peripheral industry. In C. Bliss \& de Macedo, J. B. (Eds.), Unity with Diversity in the European Economy: The Community's Southern Frontier (pp. 56-75), Cambridge: Cambridge University Press.

Lancheros, S., \& Demirel, P. (2012). Does Finance Play a Role in Exporting for Service Firms? Evidence from India. The World Economy, 35(1), 44-60.

Lanz, R., \& Maurer, A. (2015). Services and global value chains: Some evidence on servicification of manufacturing and services networks. Journal of International Commerce, Economics and Policy, 6(3), doi: https://doi.org/10.1142/S1793993315500143

Lapatinas, A. (2019). The effect of the Internet on economic sophistication: An empirical analysis. Economics Letters, 174, 35-38.

Lapatinas, A., \& Litina, A. (2019). Intelligence and economic sophistication. Empirical Economics, 57(5), 1731-1750.

Leamer, E. E., \& Storper, M. (2001). The economic geography of the internet age. Journal of International Business Studies, 32(4), 641-665.

Lee, H. H., \& Ries, J. (2016). Aid for trade and greenfield investment. World Development, 84(C), 206-218.

Lennon, C. (2008). Trade in Services and Trade in Goods: Differences and Complementarities (PSE Working Papers 2008-52).

Levy Yeyati, E. L., Panizza, U., \& Stein, E. (2007). The cyclical nature of North-South FDI flows. Journal of International Money and Finance, 26(1), 104-130.

Li, D., Moshirian, F., \& Ah-Boon Sim, A.-B. (2003). The determinants of intra-industry trade in insurance services. Journal of Risk and Insurance, 70(2), 269-287.

Li, X., Greenaway, D., Hine, X., \& R. C. (2003). Imports of Services and Economic Growth: A Dynamic Panel Approach (Working Paper). SETI, Belgium.

Lin, F. (2015). Estimating the effect of the Internet on international trade. The Journal of International Trade and Economic Development, 24(3), 409-428.

Linder, S. B. (1961). An essay on trade and transportation. Upsala, Stockholm.

LMoshirian, F., Li, D., \& Sim, A. (2005). Intra-industry trade in financial services. Journal of International Money and Finance, 24(7), 1090-1107.

Lodefalk, M. (2013). Servicification of manufacturing-evidence from Sweden. International Journal of Economics and Business Research, 6(1), 87-113.

Loungani, P., Mishra, S., Papageorgiou, C., \& Wang, K. (2017). World Trade in Services: Evidence from A New Dataset. IMF Working, International Monetary Fund, Washington, DC, Paper WP/17/77.

Marvasti, A. (1994). International trade in cultural goods: A cross-sectional analysis. Journal of Cultural Economics, 18(2), 135-148.

Mattes, A., Meinen, P., \& Pavel, F. (2012). Goods follow bytes: The impact of ICT on EU trade (DIW Berlin Discussion Paper No. 1182). 
Mattoo, A., \& Stern, R. M. (2007). A Handbook of International Trade in Services. Oxford: Oxford University Press.

McGuire, S. (2002). Trade in Services - Market Access Opportunities and the Benefits of Liberalization for Developing Countries. Policy Issues in International Trade and Commodity Study Series No.19. UNCTAD/ITCD/TAB/20, UNCTAD, Geneva.

Meijers, H. (2012). Does the Internet Generate Economic Growth, International Trade, or Both? (UNU-MERIT Working Papers 2012-050). UNU, WIDER, Helsinki, Finland.

Mirza, D., \& Nicoletti, G. (2004). What Is so Special About Trade in Services? Leverhulme Centre for Research on Globalisation and Economic Policy (Research Paper, 2004/02).

Morgan, W., \& Snowden, N. (2007). Comparative advantage and the gains from financial trade: A reappraisal. The World Economy, 30(2), 342-362.

Nagel, K., Herzer, D., \& Nunnenkamp, P. (2015). How does FDI affect health? International Economic Journal, 29(4), 655-679.

Nickell, S. (1981). Biases in dynamic models with fixed effects. Econometrica, 49(6), 1417-1426.

Nordås, H. K. (2010). Trade in goods and services: Two sides of the same coin? Economic Modelling, 27(2), 496-506.

Nyahoho, E. (2010). Determinants of comparative advantage in the international trade of services: An empirical study of the Hecksher-Ohlin approach. Global Economy Journal, 10(1), 1-24.

OECD. (2015). Innovation Policies for Inclusive Growth. OECD Publishing, Paris.

Osakwe, P. N., Santos-Paulino, A. U., \& Dogan, B. (2018). Trade dependence, liberalization, and exports diversification in developing countries. Journal of African Trade, 5(1/2), 19-34.

Pain, N., \& van Welsum, D. (2005). International production relocation and exports of services. $O E C D$ Economic Studies, OECD, Paris, 2004(1), 67-94.

Parteka, A., \& Tamberi, M. (2013). What determines export diversification in the development process? Empirical assessment. The World Economy, 36(6), 807-826.

Paunov, C. (2013). Innovation and Inclusive Development: A Discussion of the Main Policy Issues. OECD Science (Technology and Industry Working Paper No. 2013/1). OECD Publishing.

Paunov, C., \& Rollo, V. (2016). Has the internet fostered inclusive innovation in the Developing World? World Development, 78(C), 587-609.

Portugal-Perez, A., \& Wilson, J. S. (2012). Export performance and trade facilitation reform: Hard and soft infrastructure. World Development, 40(7), 1295-1307.

Riker, D. (2014). Internet Use and Openness to Trade (Working Paper No. 2014-12C). U.S. International Trade Commission, Office of Economics, United States.

Roodman, D. M. (2009). A note on the theme of too many instruments. Oxford Bulletin of Economics and Statistics, 71(1), 135-158.

Roy, M. (2019). Elevating Services: Services Trade Policy, WTO Commitments, and Their Role in Economic Development and Trade Integration (WTO staff working Paper ERSD-2019-01). World Trade Organization, Geneva, Switzerland.

Jean, R., \& Kim, D. (2020). Internet and SMEs' internationalization: The role of platform and website. Journal of International Management, 26(1). doi: https://doi.org/10.1016/j.intman.2019.100690 
Sahoo, P., \& Dash, R. K. (2014). India's surge in modern services exports: Empirics for policy. Journal of Policy Modeling, 36(6), 1082-1100.

Sahoo, P., \& Dash, R. K. (2017). What drives India's surge in service exports? The World Economy, 40(2), 439-461.

Sandeep, K. (2011). Determinants of export services of USA with its Asian partners: A panel data analysis. Eurasian Journal of Business and Economics, 4(8), 101-117.

Sapir, A., \& Lutz, E. (1981). Trade in Services: Economic Determinants and Development-Related Issues (World Bank Working Paper No. 480) World Bank, Washington, DC.

Schulze, G. (1999). International trade in arts. Journal of Cultural Economics, 23(1), 109-136.

Shingal, A. (2010). How much do agreements matter for services trade? MPRA Paper 32815, University Library of Munich, Germany.

Squalli, J., \& Wilson, K. (2011). A new measure of trade openness. The World Economy, 34(10), 1745-1770.

Stern, R. M., \& Hoekman, B. M. (1987). Issues and data needs for GATT negotiations on services. The World Economy, 10(1), 39-60.

Te Velde, D. W., \& Razzaque, M. A. (2013). Future Directions of Aid for Trade. In Assessing Aid for Trade; Effectiveness, Current Issues and Future Directions, Commonwealth Secretariat, ODI, London, UK.

Timmis, J. (2012). The Internet and International Trade in Goods. Discussion Papers in Economics 12/03, University of Nottingham, United Kingdom.

Van Der Marel, E. (2012). Determinants of Comparative Advantage in Services (Working Paper No. 87). FIW, Vienna.

Vardanyan, E. (2019). Do Remittances Worsen Export Diversification? Economics (Discussion Paper No. 2019-46).

Vemuri, V. K., \& Siddiqi, S. (2009). Impact of commercialization of the Internet on international trade: A panel study using the extended gravity model. The International Trade Journal, 23(4), 458-484.

Visser, R. (2019). The effect of the Internet on the margins of trade. Information Economics and Policy, $46,41-54$.

Wong, K. N., Tang, T. C., \& Fausten, D. K. (2009). Foreign direct investment and services trade: Evidence from Malaysia and Singapore. Global Economic Review, 38(3), 265-276.

Wren-Lewis, S., \& Driver, R. (1998). Real Exchange Rates for the Year 2000. Policy Analyses in International Economics No. 54, Institute for International Economics.

WTO. (2019a). World trade statistical Review 2019. World Trade Organization, Geneva. Retrieved from https://www.wto.org/english/res_e/statis_e/wts2019_e/wts19_toc_e.htm

WTO. (2019b). World trade report 2019: The future of services trade. WTO Secretariat, Geneva. Southeastern Europe. Retrieved from https://www.wto.org/english/news_e/news19_e/wtr_09oct19_e.htm

WTO. (2019c). Market Access for Products and Services of Export Interest to Least Developed Countries. Note by the Secretariat (WT/COMTD/LDC/W/67) for the Sub-Committee on Least Developed Countries, October 2019, World Trade Organization, Geneva, Switzerland.

Yanikkaya, H. (2003). Trade openness and economic growth: A cross-country empirical investigation. Journal of Development Economics, 72(1), 57-89.

Zhu, S., \& Fu, X. (2013). Drivers of export upgrading. World Development, 51, 221-233. 
Appendix 1. Definition and Source of Variables

\begin{tabular}{l} 
Variables Definition \\
\hline This is the Herfindahl index, also referred \\
sometimes to as the Hirschman-Herfindahl \\
index. It has been computed as follows: \\
$H H I=\frac{\sum_{k} s_{k}^{2}-1 / n}{1 / n}$ where $s_{k}={ }^{x_{k}} / \sum_{k=1}^{n} x_{k}$
\end{tabular}

represents the share of services export line $\mathrm{k}$ (with amount exported $x_{k}$ ) in total services exports: $x_{k}$ stands for the amount of services exports associated with the services line "k"; n represents the total number of the services export lines (k) and $n=\sum_{k=1}^{n} k$. The calculated Author's calculation based on data extracted from the database developed by the International Monetary Fund (IMF) on the international trade in services (see online at: https://data.imf.org/?sk=07109577-E65D-4CE1-BB21-0 CB3098FC504) - See also Loungani et al. (2017). The data used to compute the HHI indicator are sectoral data on services exports at 2-digit level, which is the maximum digit-level of disaggregated data available on services exports. In particular, we have relied on 11 major sectors of services (categories of services) - at the 1-digit level - and used the disaggregated data on services exports for sub-sectors at the 2-digit level. These 11 major services sectors are as follows (the sub-sectors are in brackets):

1. Charges for the use of intellectual property n.i.e.;

2. Construction (Construction abroad; Construction in reporting economy);

3. Financial services (Financial Explicitly charged and other financial services; Financial intermediation services indirectly measured -FISIM-);

4. Insurance and pension services (Auxiliary insurance services; Direct insurance; Pension and standardized guaranteed services; Reinsurance);

indicator has been normalized so that its values 5. Maintenance and repair services n.i.e.;

range between 0 and 100. Higher values of this 6. Manufacturing services on physical inputs owned by index indicate greater services export concentration, while lower values show greater services export diversification. others (Goods for processing abroad; Goods for processing in reporting economy);

7. Other Business Services (Professional and management consulting services; Research and development services; Technical, trade-related, and other business services);

8. Personal, cultural, and recreational services (Audiovisual and related services; Other personal, cultural, and recreational services);

9. Telecommunications, computer, and information senvices (Computer services; Information services; Telecommunications services);

10. Transport (Air Transport; Other mode of Transport; Postal and courier services; Sea Transport);

11. Travel (Business; Personal).

This variable represents the Theil index of services export concentration. It has been calculated using the following formula (for example see Agosin et al, 2012; Cadot et al.,

THEIL 2011): THEIL $=\frac{1}{n} \sum_{k=1}^{n} \frac{x_{k}}{\mu} \ln \left(\frac{x_{k}}{\mu}\right)$, where $\mu=\frac{1}{n} \sum_{k=1}^{n} x_{k}$ Author's calculation based on the same data (extracted from the IMF database on the international trade in services) used to compute the HHI indicator.

$\mathrm{n}$ represents the total number of the (services) export lines (k) $n=\sum_{k=1}^{n} k$;

$x_{k}$ stands for the amount of services exports associated with the services line "k". 
Appendix 1. Continued

\begin{tabular}{cll}
\hline Variables & \multicolumn{1}{c}{ Definition } & \multicolumn{1}{c}{ Sources } \\
\hline INTERNET & $\begin{array}{l}\text { Share (\%) of individuals using the Internet in the } \\
\text { total population. }\end{array}$ & World Development Indicators (WDI), 2019 \\
\hline PATENT & $\begin{array}{l}\text { Number of patents granted to the residents of a } \\
\text { country by its local national patent office. }\end{array}$ & $\begin{array}{l}\text { World Intellectual Property Organization (WIPO) } \\
\text { statistical database See online at: } \\
\text { https://www3.wipo.int/ipstats/index.htm?tab=patent }\end{array}$ \\
\hline MERCHGR & $\begin{array}{l}\text { This is the growth rate (\%) of total merchandise } \\
\text { exports. }\end{array}$ & Author's calculation based on data from the WDI. \\
\hline GDPC & $\begin{array}{l}\text { This is the per capita Gross Domestic Product } \\
\text { (constant } 2010 \text { US\$) }\end{array}$ & WDI \\
\hline
\end{tabular}

This is the measure of trade openness suggested by Squalli and Wilson (2011). It is calculated as

OPEN the share of the sum of exports and imports of Authors' calculation based on data extracted from the goods and services in GDP, adjusted by the WDI proportion of a country's trade level relative to the average world trade (see Squalli and Wilson, 2011).

This is the average of the gross primary school

EDU enrollment (\%), gross secondary schoo enrollment $(\%)$, and gross tertiary school Author's calculation based on data collected from the enrollment (\%).

This is the indicator of financial development. It is a composite index of four indicators of financial development, which are the liquid liabilities (\% GDP); the private credit by deposit money banks and other financial institutions (\% GDP); the bank deposits (\% GDP); and the financial system deposit ( $\%$ GDP). The "FINDEV" indicator has been computed by

Author's calculation based on data on the four indicators from the World Bank's Financial Structure dataset

FINDEV relying on the factor analysis approach, including the Principal Component Analysis that allows extracting a common factor from the above-mentioned four indicators of financial development. Higher values of "FINDEV" reflect a higher depth of financial development, and lower values indicate lower levels of financial development.

This variable measures the real per capita Foreign Direct Investment (FDI) inflows (constant 2010 US\$ prices). This variable has been calculated by multiplying the FDI-to-GDP ratio by the real per capita income (constant 2010 US\$) (see for example Herzer (2011) and Nagel et al. (2015) who apply this method to compute real values FDICAP of FDI inflows). As the variable obtained contains negative values, it has been transformed as follows (see Yeyati et al. 2007): FDICAP = sign (FDICAP1) developed by Beck et al. (2000; 2009) and Čihák et al. (2012) and updated in June 2017. $* \log (1+|F D I C A P 1|)(2)$, where "FDICAP1" is the variable obtained by multiplying FDI-to-GDP ratio by the real per capita income (constant 2010 US\$). $|F D I C A P 1|$ refers to the absolute value of the variable "FDICAP1".

Author's calculation based on data on FDI inflows (\% GDP) from the United Nations Conference on Trade and Development (UNCTAD) database, and data on real per capita income (constant 2010 US\$) from the WDI. 
Appendix 1. Continued

\begin{tabular}{|c|c|c|}
\hline Variables & Definition & Sources \\
\hline POP & This is the measure of the total Population & WDI, 2019 \\
\hline PRODCONC & $\begin{array}{l}\text { This is the index of overall export product } \\
\text { concentration. It is calculated using the Theil } \\
\text { Index, and following the definitions and methods } \\
\text { used in Cadot et al. (2011). The overall Theil } \\
\text { index of export product concentration is the sum } \\
\text { of the extensive component (increase in the } \\
\text { number of new export products or trading } \\
\text { partners) and the intensive component (the } \\
\text { shares of export volumes across active products } \\
\text { or trading partners) of the "PRODCONC" } \\
\text { variable. The computation of the index has been } \\
\text { based on a classification of products into } \\
\text { "Traditional", "New", or "Non-Traded" products } \\
\text { categories. A rise in the values of } \\
\text { "PRODCONC" index signifies an increase in the } \\
\text { degree of overall export product concentration, } \\
\text { while lower values of this index indicates greater } \\
\text { export product diversification. }\end{array}$ & $\begin{array}{l}\text { Details on the calculation of this Index could be found } \\
\text { online in the International Monetary Fund's } \\
\text { Diversification Toolkit - See data online at: } \\
\text { https://data.imf.org/?sk=3567E911-4282-4427-98F9-2B } \\
\text { 8A6F83C3B6 }\end{array}$ \\
\hline INST & $\begin{array}{l}\text { This is the variable measuring the institutional } \\
\text { and governance quality in a given country. It has } \\
\text { been computed by extracting the first principal } \\
\text { components (based on factor analysis) of the } \\
\text { following six indicators of quality of institutions } \\
\text { and governance. These indicators include a } \\
\text { measure of political stability and absence of } \\
\text { violence/terrorism; an index of regulatory } \\
\text { quality; an index of rule of law; a government } \\
\text { effectiveness index; an index of voice and } \\
\text { accountability; and an index of corruption. } \\
\text { Higher values of the synthetic index are } \\
\text { associated with better governance and } \\
\text { institutional quality, while lower values reflect } \\
\text { worse governance and institutional quality. }\end{array}$ & $\begin{array}{l}\text { Data on the components of the variable "INST" has been } \\
\text { collected from World Bank Governance Indicators } \\
\text { (WGI) developed by Kaufmann, Kraay and Mastruzzi } \\
\text { (2010) and recently updated. }\end{array}$ \\
\hline
\end{tabular}


Appendix 2. List of Countries Contained in the Full Sample

\begin{tabular}{|c|c|c|c|c|c|}
\hline \multicolumn{6}{|c|}{ Full sample } \\
\hline Albania & Chile & Grenada & Libya & Pakistan & Tanzania** \\
\hline Algeria & Colombia & Guatemala & Lithuania & Panama & Thailand \\
\hline Angola** & Comoros** & Guinea** & Luxembourg & Paraguay & Togo $* *$ \\
\hline Antigua and Barbuda & Democratic Republic of Congo** & Guyana & Macedonia, FYR & Peru & Tunisia \\
\hline Argentina & Congo, Republic of & Honduras & Madagascar** & Philippines & Turkey \\
\hline Armenia & Costa Rica & Hong Kong SAR & Malawi** & Poland & Uganda** \\
\hline Austria & Croatia & Hungary & Malaysia & Portugal & Ukraine \\
\hline Bahrain & Cyprus & India & Mali** & Romania & United States \\
\hline Bangladesh** & Czech Republic & Indonesia & Malta & Russia & Uruguay \\
\hline Barbados & Côte d'Ivoire & Iran & Mauritius & Rwanda** & Vanuatu \\
\hline Belarus & Denmark & Ireland & Mexico & Saudi Arabia & Venezuela \\
\hline Belgium & Dominican Republic & Israel & Moldova & Senegal $* *$ & \\
\hline Belize & Ecuador & Italy & Mongolia & Seychelles & \\
\hline Benin** & Egypt & Jamaica & Morocco & Sierra Leone** & \\
\hline Bhutan** & El Salvador & Jordan & Mozambique** & Slovak Republic & \\
\hline Botswana & Estonia & Kazakhstan & Myanmar** & Slovenia & \\
\hline Brazil & Finland & Kenya & Namibia & South Africa & \\
\hline Bulgaria & France & Korea & $\mathrm{Nepal}^{* *}$ & Sri Lanka & \\
\hline Burkina Faso** & Gabon & Kuwait & Netherlands & St. Lucia & \\
\hline Burundi** & Gambia** & Kyrgyz Republic & Nicaragua & Sudan** & \\
\hline Cabo Verde & Georgia & Lao P.D.R.** & Niger** & Swaziland & \\
\hline Cambodia** & Germany & Lebanon & Nigeria & Sweden & \\
\hline Cameroon & Ghana & Lesotho** & Norway & Switzerland & \\
\hline Canada & Greece & Liberia** & Oman & Tajikistan & \\
\hline
\end{tabular}

(Note) The symbol "**" refers to Least developed countries (LDCs) in the full sample.

Appendix 3. Descriptive Statistics on Variables Used in the Model

\begin{tabular}{cccccc}
\hline Variable & Observations & Mean & Standard Deviation & Minimum & Maximum \\
\hline HHI & 751 & 52.227 & 29.199 & 0 & 100 \\
THEIL & 751 & 61.415 & 25.577 & 0 & 100 \\
INTERNET & 778 & 18.118 & 23.899 & 0 & 94.873 \\
FINDEV & 772 & 46.512 & 36.957 & 0 & 100 \\
OPEN & 779 & 0.004 & 0.011 & $3.28 \mathrm{e}-09$ & 0.109 \\
GDPC & 784 & 11509.840 & 17193.510 & 205.923 & 106862.7 \\
FDICAP1 & 782 & 81807.100 & 413884.900 & -396434.7 & 7018371 \\
INST & 783 & -0.020 & 2.143 & -4.901 & 4.819 \\
EDU & 603 & 209.550 & 55.330 & 46.927 & 333.873 \\
POP & 786 & $3.36 \mathrm{e}+07$ & $1.06 \mathrm{e}+08$ & 70182.33 & $1.27 \mathrm{e}+09$ \\
PATENT & 454 & 2677.915 & 11891.840 & 1.000 & 121305.500 \\
MERCHGR & 784 & 11.212 & 13.914 & -38.468 & 223.346 \\
PRODCONC & 777 & 3.298 & 1.197 & 1.09 & 6.290 \\
\hline
\end{tabular}

